\title{
Application of alkali-activated materials for water and wastewater treatment: a review
}

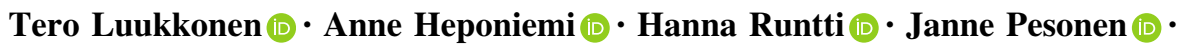 \\ Juho Yliniemi (i) Ulla Lassi $(\mathbb{C})$
}

Published online: 2 March 2019

(C) The Author(s) 2019

\begin{abstract}
Alkali-activation (or geopolymer) technology has gained a great deal of interest for its potential applications in water and wastewater treatment during the last decade. Alkali-activated materials can be prepared via a relatively simple and low-energy process, most commonly by treating aluminosilicate precursors with concentrated alkali hydroxide and/or silicate solutions at (near) ambient conditions. The resulting materials are, in general, amorphous, have good physical and chemical stability, ion-exchange properties, and a porous structure. Several of the precursors are industrial by-products or other readily available low-cost materials, which further enhances the environmental and economic feasibility. The application areas of alkali-activated materials in water and wastewater treatment are adsorbents/ion-exchangers,
\end{abstract}

T. Luukkonen $(\square)$

Kajaani University of Applied Sciences, Kuntokatu 5, 87101 Kajaani, Finland

e-mail: tero.luukkonen@oulu.fi

A. Heponiemi · H. Runtti · J. Pesonen · U. Lassi Research Unit of Sustainable Chemistry, University of Oulu, 90014 Oulu, Finland

T. Luukkonen $\cdot$ J. Yliniemi

Fibre and Particle Engineering Research Unit, University of Oulu, 90014 Oulu, Finland

U. Lassi

Kokkola University Consortium Chydenius, University of Jyvaskyla, P.O. Box 567, 67701 Kokkola, Finland photocatalysts, high-pressure membranes, filter media, anti-microbial materials, $\mathrm{pH}$ buffers, carrier media in bioreactors, and solidification/stabilization of water treatment residues. The purpose of this review is to present a comprehensive evaluation of the rapidly growing prospects of alkali-activation technology in water and wastewater treatment.

Keywords Adsorption - Alkali-activation · Catalysis · Geopolymer - Solidification/stabilization . Wastewater treatment

\section{Introduction}

Alkali-activated materials (AAMs), and geopolymers as their subgroup, are generally known as alternative low- $\mathrm{CO}_{2}$ binders, which can be used instead of Portland cement in construction (Provis 2014a, 2018). Additionally, alkali-activation technology is an important tool in promoting the circular economy, as it is a method to convert many inorganic wastes into useful products (Mehta and Siddique 2016). However, one of the emerging application areas for AAMs is in the water and wastewater treatment field (Mackenzie 2011). Drivers for this interest include simpler and less-energy intensive preparation process compared to similar materials, such as ceramics or synthetic zeolites, and useful 
properties: for instance, high mechanical strength (Luukkonen et al. 2018), good durability (PachecoTorgal et al. 2012), mesoporous structure (Glad and Kriven 2013), and ion-exchange capacity (Bortnovsky et al. 2008; Skorina 2014; O'Connor et al. 2010).

\section{Definition and chemical composition}

AAMs are amorphous aluminosilicate materials in which the calcium content affects significantly the chemical structure (Bernal et al. 2014a; Wan et al. 2017). The low-calcium AAMs (also known as geopolymers) consist of a three-dimensional and highly interconnected aluminosilicate framework (Provis and van Deventer 2009) described as sodium aluminosilicate hydrate gel $(\mathrm{N}-\mathrm{A}-\mathrm{S}-\mathrm{H}$ in cement chemist notation) (Barbosa et al. 2000; Rowles et al. 2007; García-Lodeiro et al. 2010). The structure of high calcium-content AAMs (or the $\mathrm{C}-(\mathrm{N})-\mathrm{A}-\mathrm{S}-\mathrm{H}$ gel), on the other hand, consists of cross-linked and non-cross linked structures resembling tobermorite (Bernal et al. 2014a; Myers et al. 2013, 2014; Walkley et al. 2016). Finally, also materials prepared by a reaction between phosphoric acid and an aluminosilicate precursor are sometimes referred to as phosphoric acid-activated or phosphate-based geopolymers (Le-ping et al. 2010; Louati et al. 2016a, b; Wagh 2005). The structure of phosphate-based geopolymers has been reported to consist of amorphous $\mathrm{SiO}_{2} \cdot \mathrm{Al}_{2-}$ $\mathrm{O}_{3} \cdot \mathrm{P}_{2} \mathrm{O}_{5} \cdot \mathrm{nH}_{2} \mathrm{O}$ and $\mathrm{AlH}_{3}\left(\mathrm{PO}_{4}\right)_{2} \cdot 3 \mathrm{H}_{2} \mathrm{O}$ (Wang et al. 2017).

Applications in water and wastewater treatment

AAMs have many potential applications in water and wastewater treatment, including adsorbents/ion-exchangers, membranes and filtration media, photocatalysts, and solidification/stabilization of water and wastewater treatment residues. In addition, they can be used as antibacterial materials after the incorporation of copper (Hashimoto et al. 2015) or silver (O'Connor et al. 2010) through ion exchange or addition of nanoparticles (such as silver silica nanocomposites) into the aluminosilicate matrix of AAMs (Adak et al. 2015). Although the aforementioned examples were intended as antimicrobial binders, there are numerous examples with similarly modified zeolites to indicate potential applicability for disinfection of wastewaters or groundwater (Akhigbe et al. 2014; De la Rosa-
Gómez et al. 2008a, b; Dolic et al. 2015; MpenyanaMonyatsi et al. 2012; Johari et al. 2016).

Another example of the AAM applications is as the $\mathrm{pH}$ adjustment agent. For instance, during wastewater sludge biogasification, a significant $\mathrm{pH}$ drop can occur due to the formation of acids by bacteria metabolism, making maintaining a constant $\mathrm{pH}$ challenging. AAMs are potential $\mathrm{pH}$ buffering materials as they contain free leachable alkalis in pore solution (Lloyd et al. 2010; Bumanis and Bajare 2014; Bumanis 2015; Ascensão et al. 2017; Novais et al. 2016a, 2017).

Fixed-film wastewater treatment processes (biofilm reactors) use various types of floating carrier media to allow adhesion and biofilm development. Examples of currently used carrier materials include polystyrene and lightweight expanded clay aggregate (LECA). Silva et al. (2012) prepared AAM-based biofilm carrier media (2-3 cm in size) from thermally treated $\left(800{ }^{\circ} \mathrm{C}, 2 \mathrm{~h}\right)$ tungsten mine waste mud, sodium silicate, and sodium hydroxide. One of their mixes showed good potential in terms of $\mathrm{pH}$ (should be lower than 8) and stability when submerged in water (Silva et al. 2012). Therefore, AAM-based biofilm carrier media could be a low-cost alternative for wastewater treatment.

\section{Scope of the review}

There are numerous review articles about the AAM technology discussing general properties, chemistry, possible raw materials, and various applications (Zhuang et al. 2016; Khale and Chaudhary 2007; Singh et al. 2015; Mohd Salahuddin et al. 2015; Part et al. 2015; Rao and Liu 2015; Shaikh 2013; Obonyo et al. 2011; Provis et al. 2010; Majidi 2009; Komnitsas and Zaharaki 2007). AAM adsorbents were recently reviewed by Ariffin et al. (2017) and by Siyal et al. (2018). However, the purpose of this review is to represent a more comprehensive overview about all current AAM uses in the water and wastewater treatment fields (summarized in Fig. 1). The discussed applications are adsorbents/ion-exchangers, membranes and filtration media, photocatalysts, solidification/stabilization of water and wastewater treatment residues, and other niche uses (antimicrobial materials, $\mathrm{pH}$ buffers, and carrier media for bioreactors). 


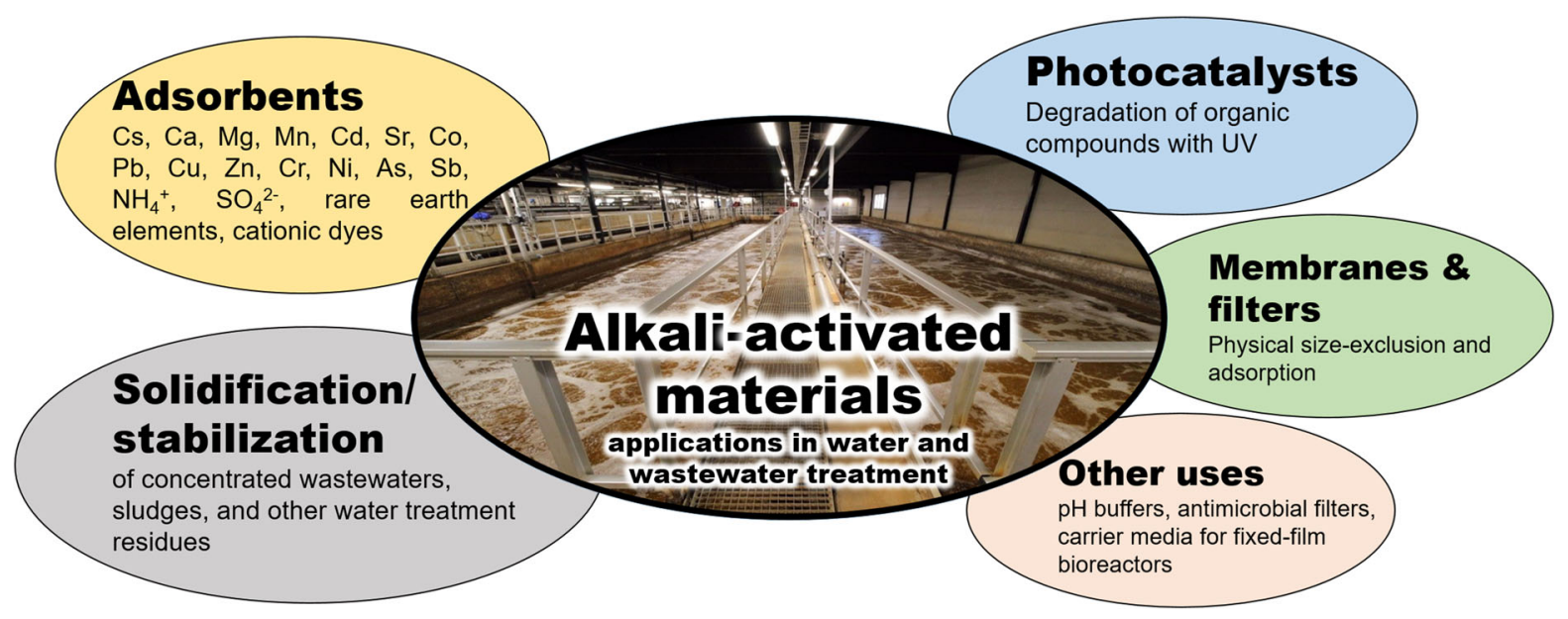

Fig. 1 Summary of current applications of alkali-activated materials in water and wastewater treatment

\section{Application as adsorbents/ion-exchangers}

Preparation

The reaction mechanisms of AAM synthesis have been discussed in numerous papers ( $\mathrm{Li}$ et al. 2010; Rees 2007; Rees et al. 2008; Bernal et al. 2014a; Provis et al. 2014). An initial description of alkali activation was as a process consisting of dissolution, rearrangement, condensation, and resolidification (Glukhovsky 1959). Provis and Van Deventer (2007) described the AAM formation mechanism in detail based on the weathering of aluminosilicate minerals. Their model included the formation of multiple, differently cross-linked aluminosilicate species and oligomerization of silicate species in concentrated aqueous solution (Provis 2014b). According to current knowledge, alkali-activation process includes the following main steps: (1) dissolution of aluminosilicate source, (2) speciation and equilibrium of aluminate and silicate, (3) gelation, (4) reorganization, and (5) polymerization and hardening (Duxson et al. 2007). In addition, the temperature, amount of water, mixing method, and physical properties of the raw materials (particle size, shape and surface area) can all significantly affect the synthesis. Also magnesium and iron can also affect the structure if they are present (Bernal et al. 2014b; García-Lodeiro et al. 2013; Bell and Kriven 2010), which makes the overall reaction and resulting structures very complicated when chemically heterogeneous raw materials are used.
The two basic approaches to preparing powdered AAM adsorbents are hydrothermal processing and the fusion method. In the hydrothermal method, solid aluminosilicate precursor is mixed with an alkaline solution, and the mixture is left to cure at (near) ambient temperature. The fusion method, on the other hand, involves mixing the solid aluminosilicate precursor with solid hydroxide and heating the mixture, followed by addition of water, filtration, washing and drying. Typically for adsorption studies, materials are pulverized as a last step. Granular or spherical AAM adsorbents (with a diameter in a millimeter range) have been fabricated by the geopolymerization-granulation process (Luukkonen et al. 2017b), by the addition of alginate and $\mathrm{Ca}^{2+}$ to promote cross-linking (Ge et al. 2017), and by the suspension and solidification method (Ge et al. 2015b).

The most commonly used aluminosilicate raw materials for AAM adsorbents are metakaolin and class F fly ash activated by sodium hydroxide and/or silicate (Table 1). Only few other aluminosilicate precursors (such as blast furnace slag, slag from LinzDonawitz (LD) converters, aluminum waste, and pyrophyllite) and activators (phosphoric acid) have been studied. It should be noted that metakaolin is purer and more consistent in chemical quality than industrial by-products and is thus more suitable for high-value products (MacKenzie 2014). For instance, adsorbents for ground water softening require a certain level of purity. Luukkonen et al. (2017a) showed that sodium-based activators resulted in better capacity 


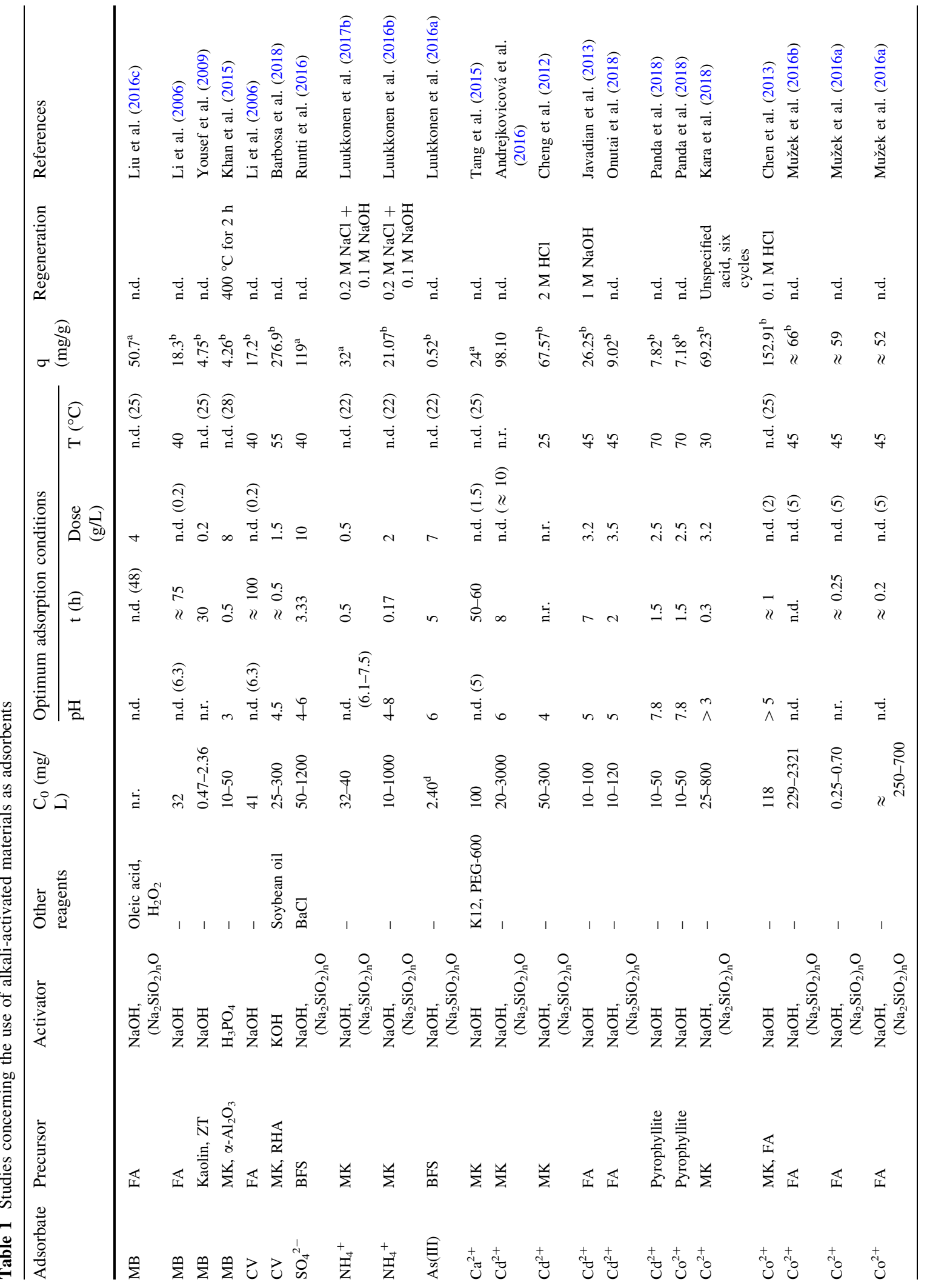




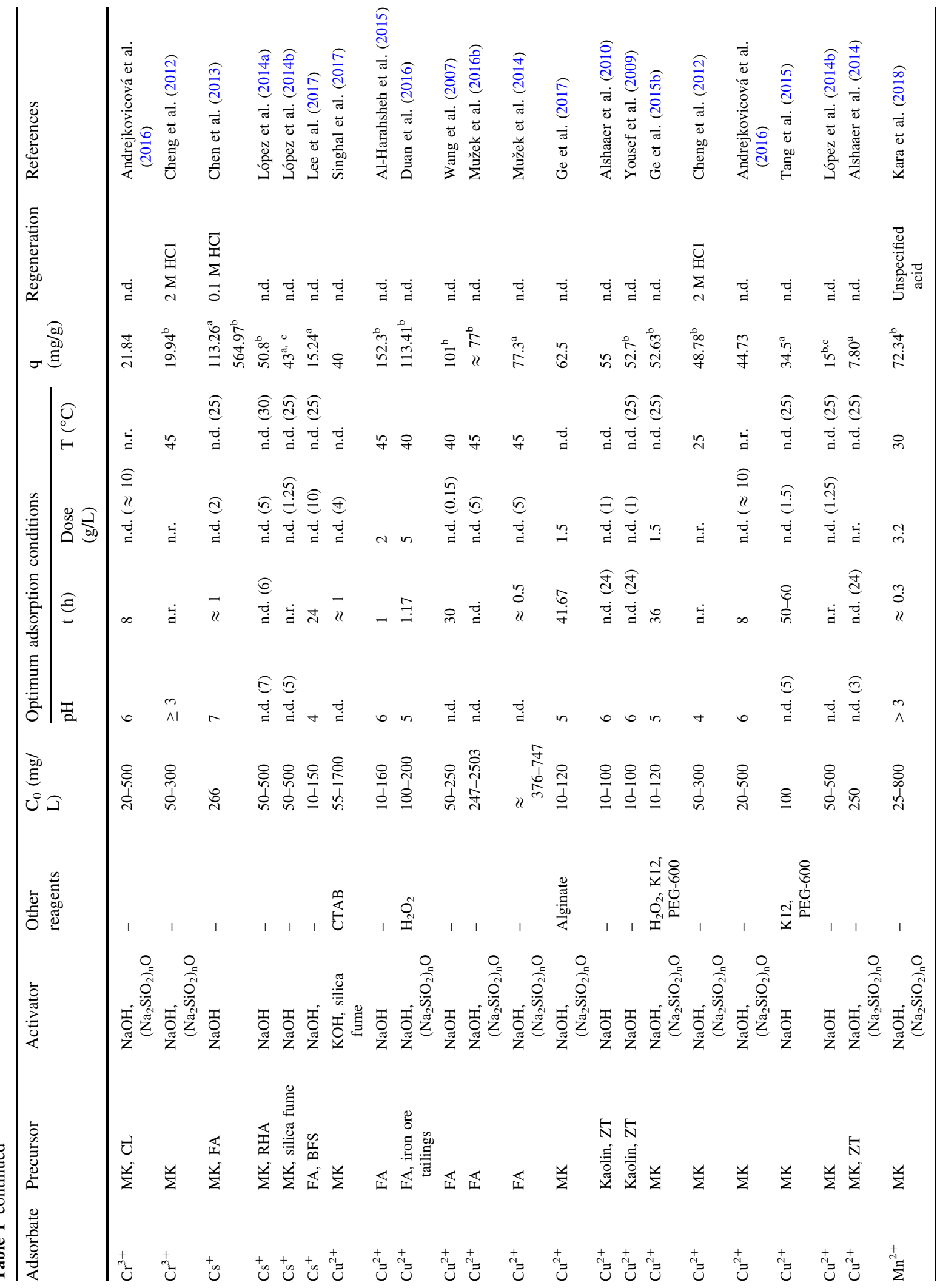




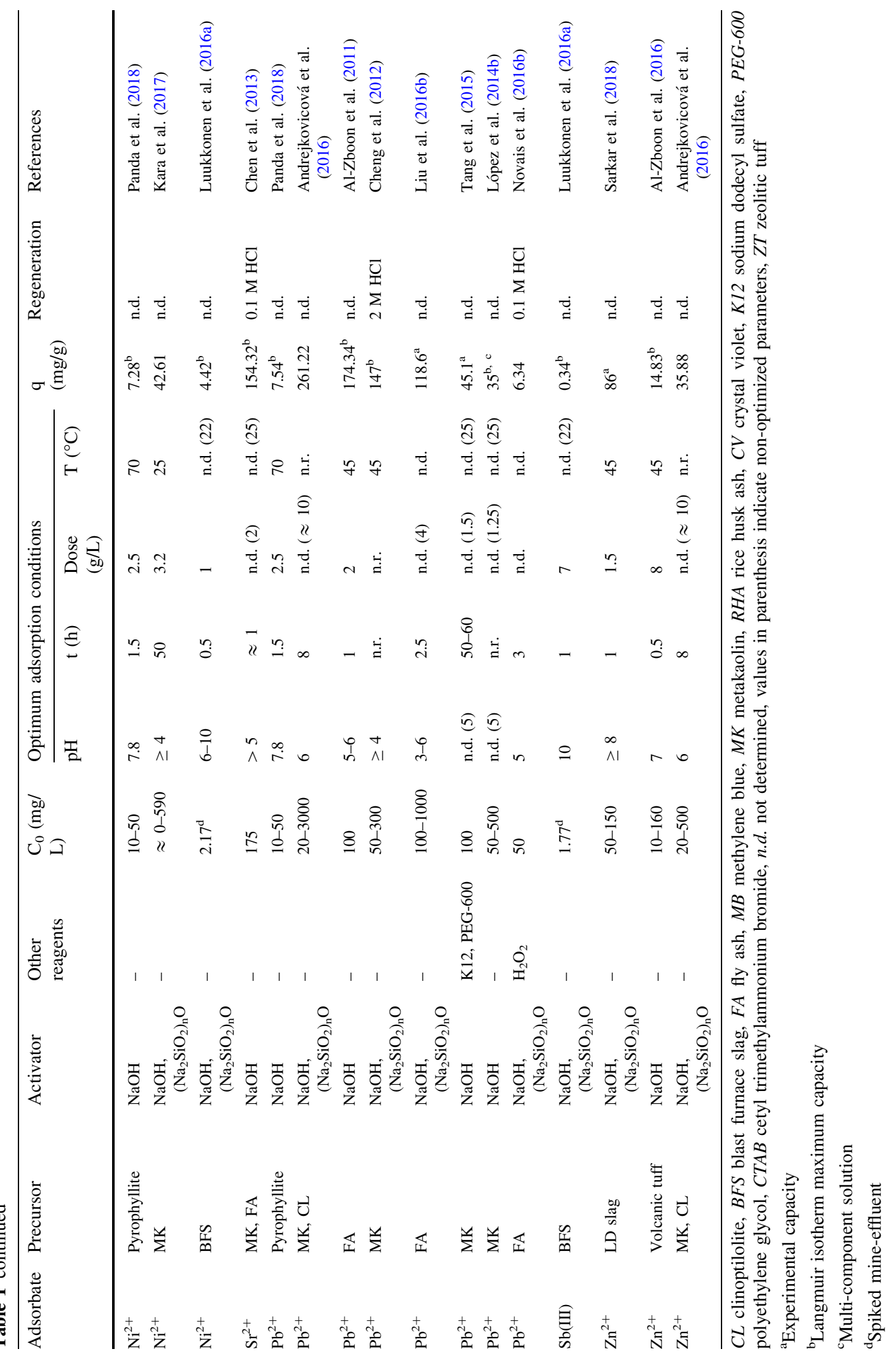


than potassium-based activators in the case of $\mathrm{NH}_{4}{ }^{+}$ adsorption by metakaolin geopolymer. In addition, some studies involved additives and other reagents such as hydrogen peroxide (blowing agent), sodium dodecyl sulfate (surfactant), cetyl trimethylammonium bromide (surfactant), polyethylene glycol (plasticizer), oleic acid (hydrophobic modifier), or sodium alginate (providing carboxyl functional groups) (Table 1). Typically, aggregates have not been incorporated in AAM adsorbents, but in some cases, zeolite has been added as a filler.

The $\mathrm{SiO}_{2} / \mathrm{Al}_{2} \mathrm{O}_{3}$ molar ratio of AAM adsorbents (Table 1) has been in the range of 0.5-19. Low $\mathrm{SiO}_{2} /$ $\mathrm{Al}_{2} \mathrm{O}_{3}$ ratios indicate that the network has more 3D structure instead of $2 \mathrm{D}$ chains and more negative charge. López et al. (2014b) showed that the $\mathrm{SiO}_{2} /$ $\mathrm{Al}_{2} \mathrm{O}_{3}$ ratio significantly affected $\mathrm{Pb}^{2+}$ adsorption: almost no adsorption occurred at $\mathrm{SiO}_{2} / \mathrm{Al}_{2} \mathrm{O}_{3}$ of 0.5 , optimum was reached at $\mathrm{SiO}_{2} / \mathrm{Al}_{2} \mathrm{O}_{3}$ ratio of 1 , and the adsorption amount fell again at $\mathrm{SiO}_{2} / \mathrm{Al}_{2} \mathrm{O}_{3}$ ratios of 1,5-2,5. In another study, the optimum was at $\mathrm{SiO}_{2} /$ $\mathrm{Al}_{2} \mathrm{O}_{3}$ of 5 in the case of $\mathrm{Cs}^{+}$adsorption.(López et al. 2014a)

The $\mathrm{Na}_{2} \mathrm{O} / \mathrm{SiO}_{2}$ ratio should be sufficiently high to depolymerize aluminosilicate via the action of alkali. However, a too high $\mathrm{Na}_{2} \mathrm{O} / \mathrm{SiO}_{2}$ ratio can inhibit the reaction (Granizo et al. 2007). The typical optimum of $\mathrm{Na}_{2} \mathrm{O} / \mathrm{SiO}_{2}$ in terms of compressive strength is approximately 0.68 (when using metakaolin as precursor), but the resulting materials exhibited a low porosity (Gao et al. 2014). The parameter $\mathrm{Na}_{2} \mathrm{O} /$ $\mathrm{Al}_{2} \mathrm{O}_{3}$, on the other hand, describes how well the negative charge of the aluminosilicate network is balanced (for instance by $\mathrm{Na}^{+}$); and consequently, a value of approximately one is an optimum. Higher $\mathrm{Na}_{2} \mathrm{O} / \mathrm{Al}_{2} \mathrm{O}_{3}$ ratios increase the instability of the AAM, which can be observed as disintegration when immersed in water (Pimraksa et al. 2011) and as formation of efflorescence. The $\mathrm{Na}_{2} \mathrm{O} / \mathrm{SiO}_{2}$ and $\mathrm{Na}_{2} \mathrm{O} /$ $\mathrm{Al}_{2} \mathrm{O}_{3}$ ratios have varied between $0.01-1$ and 0.02-2.4, respectively, in AAM adsorbents (Table 1). Finally, the $\mathrm{H}_{2} \mathrm{O} / \mathrm{Na}_{2} \mathrm{O}$ ratio of AAM adsorbents has varied within the range 9-22. A large $\mathrm{H}_{2} \mathrm{O} / \mathrm{Na}_{2} \mathrm{O}$ ratio increases channel formation in the material but decreases surface area: ratios of 18-19 and 21-22 resulted in approximately $37-39$ and $3-9 \mathrm{~m}^{2} / \mathrm{g}$ specific surface areas, respectively (Ge et al. 2015a).
According to Landi et al. (2013), increasing the water amount increases total porosity and the average pore diameter of AAMs because water acts as pore-forming agent.

When AAM adsorbents are prepared using the fusion method, solid sodium hydroxide is reacted with fly ash (weight ratio $0.8-1.2$ ) at $250-600{ }^{\circ} \mathrm{C}$ for $1-2 \mathrm{~h}$ and water is subsequently added at a liquid-to-solid weight ratio of 4.0-4.5 ( $\mathrm{Li}$ et al. 2006; Javadian et al. 2013; Wang et al. 2007). Increasing the fusion temperature and the amount of $\mathrm{NaOH}$ up to a certain value increases the adsorption efficiency, possibly by increasing the structure porosity (Wang et al. 2007). However, the high temperature of the fusion method could decrease the environmental feasibility of the method. One interesting variant of the fusion method is the reaction of $\mathrm{NaOH}$ with kaolin (optimum at weight ratio of over 2.2) at elevated temperature (500-700 ${ }^{\circ} \mathrm{C}$, at least $14 \mathrm{~h}$ ) and subsequent rinsing with distilled water $(800 \mathrm{~mL} / 1 \mathrm{~g}$ of product) (Naghsh and Shams 2017). The benefit of this synthesis method was that kaolin did not need a separate dehydroxylation step into metakaolin.

Important physico-chemical characteristics of adsorbents and catalysts include specific surface area, pore size distribution, and zeta potential. Specific surface area AAMs is typically in the range of $17-56 \mathrm{~m}^{2} / \mathrm{g}$ (Bortnovsky et al. 2008; Wang et al. 2007; Luukkonen et al. 2016b). However, specific surface areas up to $114 \mathrm{~m}^{2} / \mathrm{g}$ have been reported (Lee et al. 2016a). With an addition of surfactant, the specific surface area can be further increased: for instance, from 137 to $216 \mathrm{~m}^{2} / \mathrm{g}$ by using cetyl trimethylammonium bromide (Singhal et al. 2017). AAMs are usually mesoporous (i.e., pore size 2-50 nm), but also micro $(<2 \mathrm{~nm})$ and macro pores $(>50 \mathrm{~nm})$ are present (Bortnovsky et al. 2008; Luukkonen et al. 2016b). The zeta potential of AAMs is negative due to the negative charge of the aluminosilicate framework structure (Luukkonen et al. 2016b; López et al. 2014b). The point of zero charge for metakaolin geopolymer has been determined to be at pH 4.5 (Luukkonen et al. 2016b) and 8.0 for alkali-activated LD slag (which is a highcalcium system) (Sarkar et al. 2018). 
Adsorption of alkaline earth metals, transition metals, metalloids, and rare earth elements

The main sorption mechanism of AAMs is thought to be ion exchange similar to zeolites (Bortnovsky et al. 2008) which occurs at both interlayer and surface sites (Provis et al. 2015). Ion exchange can be presented on a general level with Reaction 1 , where $\mathrm{M}^{+}$is a cation with a higher affinity than $\mathrm{Na}^{+}$(in this example, $\mathrm{Na}$ is used as the charge-balancing cation). With highcalcium AAMs, the tobermorite-like phases have cation-exchange/adsorption properties as well (Guo and Shi 2017).

$$
\begin{aligned}
& {[\mathrm{Al}-\mathrm{Si} \text { framework }]-\mathrm{Na}^{+}+\mathrm{M}^{+}(\mathrm{aq})} \\
& \quad \leftrightarrow[\mathrm{Al}-\mathrm{Si} \text { framework }]-\mathrm{M}^{+}+\mathrm{Na}^{+}(\mathrm{aq})
\end{aligned}
$$

Due to the high alkalinity of AAMs and subsequent increase of $\mathrm{pH}$, some transition metal cations can precipitate in addition to sorption (Novais et al. 2016b). However, the increase of $\mathrm{pH}$ is modest in well-buffered effluents: for example, municipal wastewater $\mathrm{pH}$ increased significantly only when over $5 \mathrm{~g} / \mathrm{L}$ metakaolin geopolymer adsorbent powder doses were used (Luukkonen et al. 2017b). Furthermore, it has been shown that careful flushing with water decreases $\mathrm{pH}$ of AAMs to near neutral values (Ge et al. 2015a). Finally, the removal of some anionic impurities, for instance $\mathrm{H}_{2} \mathrm{AsO}_{3}{ }^{-}$, has been explained by the formation of secondary mineral phases, such as hydrotalcite (which is, as layered double hydroxide, anion exchanger), during alkali-activation (Luukkonen et al. 2016a).

AAMs have been studied for the removal of several potentially toxic elements: for instance, $\mathrm{Co}, \mathrm{Pb}, \mathrm{Cu}$, $\mathrm{Zn}, \mathrm{Cr}, \mathrm{Ni}, \mathrm{As}$, and $\mathrm{Sb}$ (Table 1). Exposure to these metal(loid)s can be acutely toxic for humans and other organisms at elevated concentrations whereas a prolonged exposure to lower concentrations can cause cancers, for instance (Chowdhury et al. 2016; Järup 2003; Tchounwou et al. 2012). The origin of these metal(loid)s to the aquatic environment is from various industrial (point) sources and other human activities but also through dissolution of natural geological depositions. The World Health Organization guideline maximum concentrations for $\mathrm{Cu}, \mathrm{Ni}, \mathrm{Cr}$ (total), $\mathrm{Sb}, \mathrm{Pb}, \mathrm{As}$, and $\mathrm{Cd}$ in drinking water are 2000 , $70,50,20,10,10$, and $3 \mu \mathrm{g} / \mathrm{L}$, respectively (World Health Organization 2011a). For Co and Zn, there are no established guideline values (World Health Organization 2011a; Kim et al. 2006). As can be seen from Table 1, AAMs represent promising removal efficiencies and regenerability for above-mentioned metal (loid)s in many reported cases. For instance, Ge et al. (2015b) prepared porous metakaolin-based geopolymeric spheres, which had higher capacity than commercial spherical molecular sieves (4 A zeolite) for $\mathrm{Cu}$ removal and acceptable stability in acidic conditions. However, as a large majority of the experiments in Table 1 is conducted with synthetic wastewaters, more research is needed before the practical potential of AAM adsorbents can be realistically evaluated.

Calcium and magnesium are essential minerals for human health but their presence at elevated concentrations causes the formation of scale in domestic and industrial water networks and heat exchangers (World Health Organization 2011b). Tang et al. (2015) used porous metakaolin-based geopolymer to adsorb $\mathrm{Ca}^{2+}$ but their material was characterized by a relatively low capacity $(24 \mathrm{mg} / \mathrm{g})$ and a long required contact time (equilibrium was reached after 50-60 h). Naghsh and Shams (2017) obtained regenerable water-softening geopolymer (for $\mathrm{Mg}$ and $\mathrm{Ca}$ removal) from kaolin using a novel fusion method: their material was comparable to commercial water softeners (for instance 4A zeolite) in terms of efficiency. Experiments were conducted in both synthetic and real groundwater (Naghsh and Shams 2017).

Rare earth elements (REEs) are critical resources for several high technology applications and thus their demand is increasing. REEs are typically present as relatively low concentrations within minerals, which requires efficient extracting technologies. Furthermore, the recycling of REEs from various end-of-life products is challenging. Fiket et al. (2018) reported a preliminary study in which they adsorbed $\mathrm{Ce}, \mathrm{La}, \mathrm{Nd}$, Pm, Dy, Er, Eu, Gd, Ho, Lu, Sc, Sm, Tb, Tm, Y, and $\mathrm{Yb}$ from multi-element solution (total concentration of REEs was $1 \mathrm{mg} / \mathrm{L}$ ) on coal fly ash-geopolymer. Their results demonstrate that all studied REEs were adsorbed quite effectively when using contact time of $120 \mathrm{~min}$ and that the geopolymer $\mathrm{SiO}_{2} / \mathrm{Na}_{2} \mathrm{O}$ ratio of 0.7-0.8 was more efficient than 1.1-1.3.

The selectivity of metakaolin-based geopolymer adsorbents has been studied in several publications with the following results: $\mathrm{Cs}^{+}>\mathrm{Pb}^{2+}>\mathrm{Cu}^{2+-}$ $>\mathrm{Zn}^{2+}>\mathrm{Ni}^{2+}>\mathrm{Cd}^{2+}$ (López et al. 2014b); $\mathrm{Pb}^{2+-}$ $>\mathrm{Cd}^{2+}>\mathrm{Zn}^{2+}>\mathrm{Cu}^{2+}>\mathrm{Cr}^{3+} \quad$ (Andrejkovicová 
et al. 2016); $\mathrm{Pb}^{2+}>\mathrm{Cd}^{2+}>\mathrm{Cu}^{2+}>\mathrm{Cr}^{3+}$ (Cheng et al. 2012); and $\mathrm{Pb}^{2+}>\mathrm{Cu}^{2+}>\mathrm{Ca}^{2+}$ (Tang et al. 2015). The results seem rather consistent although the structure of geopolymers is nonordered: the main differences are the selectivity towards $\mathrm{Cd}^{2+}$ and the order of $\mathrm{Cu}^{2+}$ and $\mathrm{Zn}^{2+}$. However, El-Eswed et al. (2012) obtained deviating results for kaolin/zeolitebased geopolymer: $\mathrm{Cu}^{2+}>\mathrm{Cd}^{2+}>\mathrm{Ni}^{2+}>\mathrm{Zn}^{2+-}$ $>\mathrm{Pb}^{2+}$. The selectivity of alkali-activated blast furnace slag was shown to be $\mathrm{Ni}^{2+-}$ $>\mathrm{As}(\mathrm{III})>\mathrm{Sb}$ (III) in mine effluent (Luukkonen et al. 2016a). Ge et al. (2017) showed that the presence of $\mathrm{Na}^{+}, \mathrm{Ca}^{2+}$, and $\mathrm{Mg}^{2+}$ decreased the adsorption efficiency of spherical metakaolin/alginate geopolymer towards $\mathrm{Cu}^{2+}$. This demonstrates that the removal efficiency in real wastewaters with a multicomponent composition and varying ionic strength is likely to be lower than those reported in Table 1.

It has been suggested that the adsorption properties of AAMs could be utilized in construction materials such as water tanks, pipes, and damns (Alshaaer et al. 2012; Yousef et al. 2009; Alshaaer et al. 2010; Hamaideh et al. 2014). Good mechanical properties combined with adsorption capacity could be obtained if zeolitic tuff is used as fine aggregate in AAM binder (Andrejkovicová et al. 2016; Huang et al. 2012). However, regeneration of such permanent installations represents a challenge.

\section{Adsorption of radioisotopes}

AAMs have been used to adsorb several elements that have radioisotopes: cesium, strontium, radium, and cobalt (Table 1). The removal of radioisotopes from water has become increasingly important since the Fukushima nuclear accident in Japan in 2011 (Kinoshita et al. 2011; Liu et al. 2014). Cesium occurs as $\mathrm{Cs}^{+}$in the aqueous environment and is highly soluble and stable (Lima 2010). Radioactive ${ }^{137} \mathrm{Cs}$ is of special concern due to its long half-life of 30.2 years. Strontium (present primarily as $\mathrm{Sr}^{2+}$ in the aqueous environment) has several radioactive isotopes, of which ${ }^{90} \mathrm{Sr}$ (half-life 28.9 years) is the most significant (Guillén et al. 2010). All isotopes of radium (commonly present as $\mathrm{Ra}^{2+}$ in low salinity conditions) are radioactive (half-lives vary from a few days up to 1600 years) (International Atomic Energy Agency 2014). AAM from metakaolin was potentially effective in adsorbing $\mathrm{Cs}$ : it was selective over $\mathrm{Pb}^{2+}, \mathrm{Cu}^{2+}$,
$\mathrm{Cd}^{2+}, \mathrm{Ni}^{2+}$, and $\mathrm{Zn}^{2+}$ and the adsorption efficiency was not affected by the presence of $\mathrm{NaCl}$ up to 10 weight-\% concentration (López et al. 2014a, b). Chuang and Liao (Chuang and Liao 2015) adsorbed $\mathrm{Cs}^{+}$on phosphate geopolymer containing potassium zinc ferrocyanide. Lee et al. (2017) used porous AAM blocks prepared from fly ash and blast furnace slag to remove $\mathrm{Cs}^{+}$. AAMs compare favorably to many other adsorbents that have been used to remove $\mathrm{Cs}^{+}$in terms of, for instance, maximum adsorption capacity (Liu et al. 2014). Chen et al. (2013) studied the removal of $\mathrm{Cs}^{+}, \mathrm{Sr}^{2+}$, and $\mathrm{Co}^{2+}$ with AAM prepared of metakaolin and fly ash and obtained very high adsorption capacities (see Table 1). It was also possible to desorb these ions with $0.1 \mathrm{M} \mathrm{HCl}$ indicating that adsorbent could be regenerated (Chen et al. 2013). Also fly ash-based AAMs are potentially effective in removing $\mathrm{Co}^{2+}$ (it should be noted that radioisotopes and non-radioactive isotopes have similar aqueous chemistry) (Mužek et al. 2016a, b). Finally, radium isotopes were removed with foamed AAM in which $\mathrm{BaSO}_{4}$ was incorporated: the material was suggested for use as a passive filtration material (Kunze et al. 2002).

\section{Adsorption of dyes}

Several AAMs have been used for the removal of the basic cationic dyes methylene blue and crystal violet (Table 1). Khan et al. (2015) adsorbed methylene blue on phosphoric acid-activated metakaolin (Langmuir capacity, $4.26 \mathrm{mg} / \mathrm{g}$ ). It was possible to regenerate the adsorbent multiple times by calcination at $400{ }^{\circ} \mathrm{C}$ for $2 \mathrm{~h}$, and the adsorption capacity in fact improved upon regeneration (Khan et al. 2015). An approximately similarly effective methylene blue adsorbent (Langmuir capacity, $4.75 \mathrm{mg} / \mathrm{g}$ ) was prepared by Yousef et al. (2009) via the $\mathrm{NaOH}$ activation of kaolin and using zeolite as filler. Li et al. (2006) prepared fly ashbased AAM via a solid-state fusion method with $\mathrm{NaOH}$ and obtained somewhat higher capacities: 18.3 and $17.2 \mathrm{mg} / \mathrm{g}$ for methylene blue and crystal violet, respectively. The most efficient AAM to date for methylene blue was prepared by Liu et al. (2016c), who obtained an experimental adsorption capacity of $50.7 \mathrm{mg} / \mathrm{g}$ : their adsorbent also showed improved porosity and was floatable due to the addition of $\mathrm{H}_{2} \mathrm{O}_{2}$. Although AAMs show some promising features for dye removal, such as the ability to be regenerated, 
their currently reported adsorption capacities are clearly inferior to that of commercially available activated carbons or several other experimental adsorbents (Rafatullah et al. 2010). However, Barbosa et al. (2018) prepared AAM from metakaolin, rice husk ash, and soybean oil (as mesostructured directing agent), used it for the adsorption of crystal violet, and obtained relatively high maximum capacity of $276.9 \mathrm{mg} / \mathrm{g}$.

\section{Adsorption of ammonium and sulfate}

Ammonium $\left(\mathrm{NH}_{4}{ }^{+}\right)$is the commonly occurring nitrogen species in, for instance, untreated municipal wastewater. Its removal has been studied extensively via ion-exchange on natural and synthetic zeolites as an alternative to the traditionally used microbial nitrification-denitrification (Couto et al. 2016; Hedström 2001; He et al. 2016; Leyva-Ramos et al. 2010; Niu et al. 2012; Zhang et al. 2011; Ye et al. 2015; Sarioglu 2005; Ji et al. 2007). In fact, anaerobic digestion followed by natural zeolite-based ion exchange had potential for the recovery of nitrogen, lower operational costs, and better nitrogen-removal performance in comparison to the conventional nitrification-denitrification or the Anammox processes (Lin et al. 2016). Luukkonen et al. (2016b) used metakaolin-based geopolymer and obtained $21.07 \mathrm{mg} / \mathrm{g}$ ammonium adsorption capacity in model solutions, which was higher than that obtained with typical natural zeolites. They also demonstrated that the removal was based on ion exchange, material could be regenerated with a solution containing $0.2 \mathrm{M}$ $\mathrm{NaCl}$ and $0.1 \mathrm{M} \mathrm{NaOH}$, and the adsorbent was effective for on-site treatment of landfill leachate (initial $\mathrm{NH}_{4}^{+} \approx 55 \mathrm{mg} / \mathrm{L}$ ) at low temperatures (Luukkonen et al. 2016b). In another study, Luukkonen et al. (2017a) used a central composite design technique to optimize the preparation of metakaolin geopolymer to maximize ammonium adsorption capacity. Using higher amounts of silicate and hydroxide, lower amounts of metakaolin, and sodium as the charge balancing cation instead of potassium during the preparation resulted in the best capacity (Luukkonen et al. 2017a). With the aforementioned optimization, it was possible to increase the maximum adsorption capacity from 21.07 to $31.70 \mathrm{mg} / \mathrm{g}$ (Luukkonen et al. 2017a). Luukkonen et al. (2017b) also prepared metakaolin geopolymer with the granulation-geopolymerization method to be used as a filter media. In a continuous small-scale pilot (Fig. 2), it was possible to consistently obtain less than $4 \mathrm{mg} / \mathrm{L}$ ammonium concentration in municipal wastewater (initial $\mathrm{NH}_{4}{ }^{+} \approx 23 \mathrm{mg} / \mathrm{L}$ ) at low temperature (approximately $10{ }^{\circ} \mathrm{C}$ ) and regenerate material multiple times with $\mathrm{NaCl} / \mathrm{NaOH}$. Bai and Colombo (2017) studied metakaolin-based geopolymer foams in the form of monolithic porous filters, which could be prepared by $3 \mathrm{D}$ printing using the direct ink writing technique. The filter was able to remove up to $95.3 \%$ of ammonium from the initial concentration of $3 \mathrm{mg} / \mathrm{L}$ $\mathrm{NH}_{4}{ }^{+}$(Bai and Colombo 2017).

Sulfate $\left(\mathrm{SO}_{4}{ }^{2-}\right)$ is a ubiquitous naturally occurring anion that is not considered toxic as such, but it can cause salinization of water bodies. Therefore, sulfate removal must be managed in several industries, such as mining (acid mine drainage) (De La Torre et al. 2011) and desalination plants (reverse osmosis reject water) (Pérez-González et al. 2012). Runtti et al.

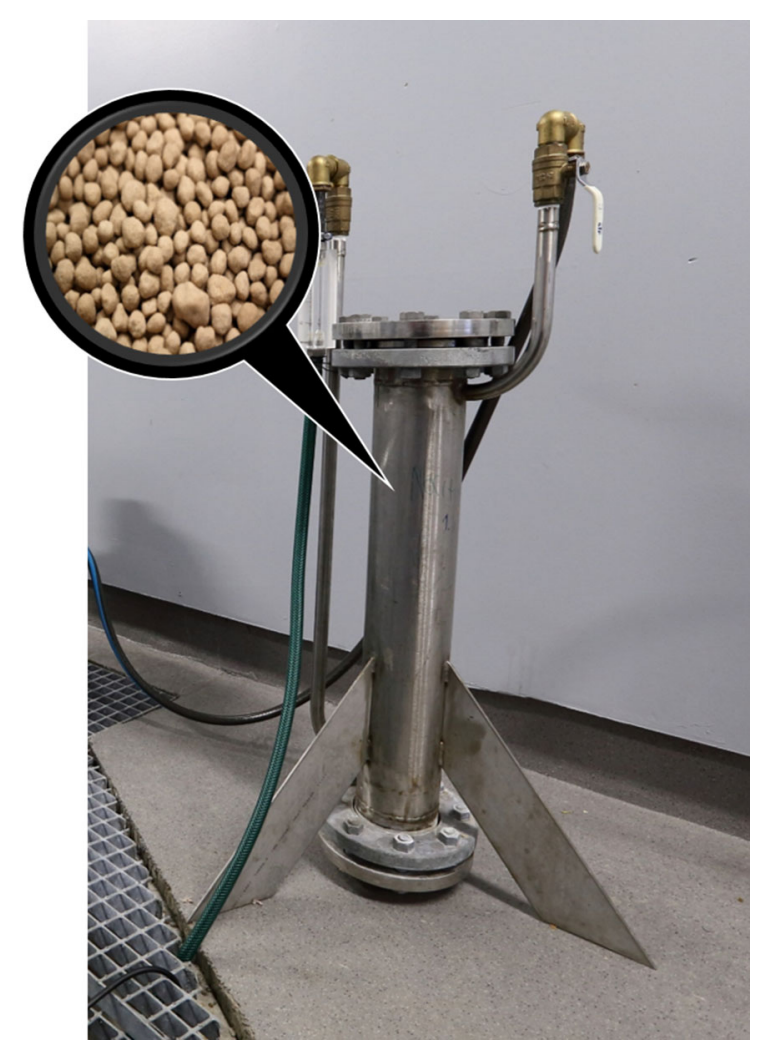

Fig. 2 Small pilot-scale set-up for ammonium removal from municipal wastewater using granulated metakaolin geopolymer (Luukkonen et al. 2017b). With this set-up, it was possible to reach $<4 \mathrm{mg} / \mathrm{L} \mathrm{NH}_{4}{ }^{+}$in cold wastewater $\left(\approx 10{ }^{\circ} \mathrm{C}\right)$ 
(2016) modified alkali-activated blast furnace slag by exchanging charge-balancing sodium cations into barium and used the obtained material to remove sulfate from synthetic wastewater $\mathrm{SO}_{4}{ }^{2--}$ $\approx 1000 \mathrm{mg} / \mathrm{L})$ and mine effluents $\left(\mathrm{SO}_{4}{ }^{2--}\right.$ $\approx 900 \mathrm{mg} / \mathrm{L}$ ). The observed adsorption capacity was relatively high, approximately $119 \mathrm{mg} / \mathrm{g}$, and it was possible to achieve very low sulfate concentrations $(<2 \mathrm{mg} / \mathrm{L})$ (Runtti et al. 2016). The proposed removal mechanism was the surface complexation or precipitation of extremely low solubility $\mathrm{BaSO}_{4}$ (Runtti et al. 2016). Zhang et al. (2018) showed by molecular dynamics simulation that cations such as $\mathrm{Na}^{+}$or $\mathrm{Mg}^{2+}$ are adsorbed on the surface hydroxyls of the NASH gel and attract $\mathrm{SO}_{4}{ }^{2-}$ ions.

\section{Thermodynamics of adsorption}

Thermodynamic parameters, standard enthalpy change $\left(\Delta \mathrm{H}^{0}\right)$, standard entropy change $\left(\Delta \mathrm{S}^{0}\right)$, and standard free energy change $\left(\Delta \mathrm{G}^{0}\right)$, provide information about the nature and thermodynamic feasibility of the adsorption process. The reported $\Delta \mathrm{H}^{\mathrm{o}}$ values of adsorption on AAMs have been generally positive (Runtti et al. 2016; Javadian et al. 2013; Al-Harahsheh et al. 2015; Duan et al. 2016; Sarkar et al. 2017; Liu et al. 2016b; Al-Zboon et al. 2011, 2016), which indicates that the adsorption efficiency increases at higher temperatures. However, one deviating result $\left(\Delta \mathrm{H}^{0}<0 \mathrm{~kJ} / \mathrm{mol}\right.$ ) was obtained by Li et al. (2006) for methylene blue removal by fly-ash based geopolymer. Further support is provided by the fact that the values of $\Delta \mathrm{S}^{0}$ are consistently positive indicating that the system entropy increases after adsorption process (Runtti et al. 2016; Javadian et al. 2013; Al-Harahsheh et al. 2015; Duan et al. 2016; Sarkar et al. 2017; Liu et al. 2016b; Al-Zboon et al. 2011, 2016). This has been explained by the separation of hydrated water molecules from the metal ion (i.e., inner-sphere complexes are formed and specific adsorption occurs) before attachment to the surface sites of AAMs, which is an energy-requiring process (Al-Zboon et al. 2011; Al-Harahsheh et al. 2015). Finally, the negative $\Delta G^{0}$ (numerical values approx. -6 to $-27 \mathrm{~kJ} / \mathrm{mol}$ ) indicate that adsorption on geopolymers is an overall spontaneous process through physical and reversible interactions (Runtti et al. 2016; Javadian et al. 2013; Al-Harahsheh et al. 2015; Duan et al. 2016; Sarkar et al. 2017; Liu et al. 2016b; Al-Zboon et al. 2011, 2016).

\section{Membranes and filters}

Alkali-activation technology allows the production of highly porous ceramic-like inorganic self-supporting membranes and filters without sintering (Bai and Colombo 2018) and subsequently could lower the production costs compared to the conventional ceramic materials. In fact, ceramic filters and membranes have many beneficial features over organic polymers but their high price has prevented more widespread use in industrial water treatment (Ciora and Liu 2003). The existing laboratory-scale studies have pointed out, as discussed below, that the performance of AAMs in membrane separation is promising and in some cases already comparable to commercially available materials. However, the majority of the published articles is so far more concentrated on the material science aspects than on the applications. This section summarizes the AAM materials for external pressure-driven membranes and gravity filtration media.

\section{Pressure-driven membranes}

Pressure-driven membranes are classified as microfiltration, ultrafiltration, nanofiltration, and reverse osmosis, based on the separation capacity. Of these classes, AAM membranes have been typically in the micro or ultrafiltration range (pore sizes 20-100 nm) (Ge et al. 2015a; Xu et al. 2015). The inherent porosity of AAM materials can be utilized for membrane application, which means that the preparation process does not necessarily require any specific additives or foaming processes. However, one of the first geopolymer membranes was prepared using the sacrificial filler method: self-assembled layers from nano-sized polystyrene spheres were prepared, covered with metakaolin-alkali silicate slurry, $200 \mathrm{MPa}$ pressure was applied for $1 \mathrm{~h}$, and curing was conducted at $50{ }^{\circ} \mathrm{C}$ for $24 \mathrm{~h}$ and the polystyrene template was dissolved with a solvent (Mallicoat et al. 2005). Ge et al. (2015a) prepared an AAM membrane via directly mixing metakaolin with sodium silicate and curing at $60{ }^{\circ} \mathrm{C}$ : the membrane had a total porosity of $62.64 \%$ and water flux values (at steady state) between 
approximately 21 and $237 \mathrm{~kg} /\left(\mathrm{m}^{2} \times \mathrm{h}\right)$ at $0.1 \mathrm{MPa}$ depending on the $\mathrm{H}_{2} \mathrm{O} / \mathrm{Na}_{2} \mathrm{O}$ ratio. Furthermore, the membrane could adsorb $\mathrm{Ni}^{2+}$ with a capacity of $43.36 \mathrm{mg} / \mathrm{g}$ (Ge et al. 2015a). Xu et al. (2015) prepared a similar membrane from metakaolin with an optimum $\mathrm{H}_{2} \mathrm{O} / \mathrm{Na}_{2} \mathrm{O}$ ratio of 18 : the membrane had water flux of $185 \mathrm{~kg} /\left(\mathrm{m}^{2} \times \mathrm{h}\right)$ at $0.3 \mathrm{MPa}$ (membrane thickness, $5.0 \mathrm{~mm}$ ) and $100 \%$ rejection rate for nanosized $\mathrm{Al}_{2} \mathrm{O}_{3}$ particles. In addition, an $\mathrm{AAM}$ membrane with potential to remove $\mathrm{Ca}^{2+}$ and $\mathrm{Mg}^{2+}$ has been reported (Li et al. 2017). Alkali-activated blast furnace slag membranes were prepared by the hydraulic pressing method: the optimum conditions for preparation were 400 bar pressure, $6 \mathrm{~h}$ drying time, and 5 min pressing time and 225 bar pressure, $8 \mathrm{~h}$ drying time, and $30 \mathrm{~min}$ pressing time for chemical oxygen demand (COD) removal (100\%) and permeation flux optimization $\left(1960 \mathrm{~kg} /\left(\mathrm{m}^{2} \times \mathrm{h}\right)\right.$, respectively (Mohammadi and Mohammadi 2017).

Another method to utilize the alkali-activation technology for membrane preparation is to first prepare amorphous AAM material and convert it into crystalline zeolite membrane using hydrothermal aging process. For instance, self-supporting $\mathrm{NaA}$ zeolite membranes have been prepared of AAM material by submerging them into water or dilute $\mathrm{NaOH}$ solution at approximately $90{ }^{\circ} \mathrm{C}$ for $6-48 \mathrm{~h}$ (Yan et al. 2012; Xuemin et al. 2011; He et al. 2013; Zhang et al. 2014, 2016). Furthermore, if the $\mathrm{Na} / \mathrm{Si}$ ratio is increased up to 1.25 , the transformation from amorphous AAM into zeolite can occur via a simple heat curing (at $60{ }^{\circ} \mathrm{C}$ ) without hydrothermal treatment (Xu et al. 2017). AAMs can also be cured into a faujasite-type zeolite by optionally adding oleic acid and aluminum powder to promote permeability (Liu et al. 2016a, 2017). Although the aforementioned membranes were used for the water-ethanol separation, it has been demonstrated that zeolite membranes also have potential in water treatment applications (Kazemimoghadam 2010; Cui et al. 2008).

\section{Filtration media}

In addition to the high pressure-driven membrane filtration, AAM materials could also be used as filtration media in sand filters, permeable reactive barriers, or point-of-use water treatment filters, as an example. In these uses, AAMs could serve as adsorptive (see Sect. 2) and/or catalytically active (see
Sect. 3) media in addition to simple physical filtration. This application requires, however, pores in the range of micro or millimeters, in addition to micro and mesoporosity, to have sufficiently high permeability. The preparation methods of highly porous AAM materials have been classified as direct foaming, sacrificial filler method, replica method, additive manufacturing, and other methods (such as granulation) (Bai and Colombo 2018). The direct foaming is the most widely used method and it involves mechanical mixing or blowing agents to introduce gas bubbles into to the fresh AAM paste (Bai and Colombo 2018). When surfactants are used, they stabilize the formed foam and resulting materials have highly interconnected pores and permeability similar to that of granular filters (Strozi Cilla et al. 2014b). Surfactants can also be produced in situ by adding, for example, vegetable oils (triacylglycerols) to the alkaline AAM suspension, which results in the saponification reaction (decomposition into glycerol and soaps) due to high pH (Cilla et al. 2017; Bai et al. 2016). In addition, albumin powder (from chicken egg white) has been studied as a surfactant for foaming AAMs with hydrogen peroxide (Bai and Colombo 2017). AAM foam was able to adsorb $95 \%$ and $87 \%$ of ammonium and copper, respectively, from synthetic wastewater when the initial concentration was $3 \mathrm{mg} / \mathrm{L}$ for each (Bai and Colombo 2017). The total and open porosities of the aforementioned foams were in the ranges of 67-88 and 60-85 vol\%, respectively (Bai and Colombo 2017; Strozi Cilla et al. 2014a; Bai et al. 2017; Cilla et al. 2017). Landi et al. (2013) prepared geopolymer filter material from metakaolin, potassium silicate, and fumed silica with highly interconnected macropores by using elemental silicon as blowing agent. The filter had $\mathrm{NH}_{4}{ }^{+}$exchange capacity, although it was concluded that only a small portion of the inner volume pores were accessible due to cavity dimensions. Pervious alkali-activated concrete (prepared of fly ash, nanosized silica, and ordinary Portland cement) could be used for phosphorus and fecal coliform removal from wastewater due to leaching of calcium and increase of $\mathrm{pH}$, respectively (Jo et al. 2015). Finally, additive manufacturing, or 3D-printing, of AAM materials is a method to produce carefully controlled pore sizes, shapes, and amounts (Bai and Colombo 2018). Examples of porous materials prepared by direct foaming, 3D printing, and geopolymerization-granulation are shown in Fig. 3. 

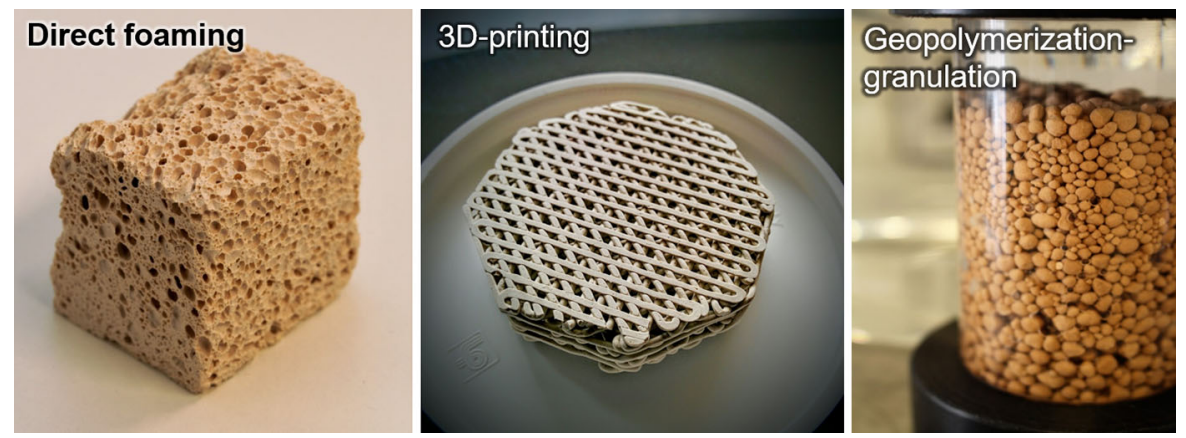

Fig. 3 Approaches for preparing porous filters by alkaliactivation: direct foaming, 3D-printing and geopolymerization-granulation (pictures are from experimental work conducted at the Fibre and Particle Engineering Research Unit,

\section{Catalysts}

AAMs have been studied as catalysts or catalyst supports for pollutant degradation in both gas and liquid phase reactions (Asim et al. 2019). In water and wastewater treatment, they have been so far applied as photocatalysts (i.e., reactive radicals are produced when the catalyst is exposed to irradiation with energy equal to or larger than the bandgap) for degradation of various dyes. AAM catalysts could be also used in other types of advanced oxidation processes and for other recalcitrant organic pollutants as well but such studies are still lacking. AAMs are interesting materials for catalysts as they can be designed to have high permeability, surface area, chemical durability, and mechanical strength together with a simple, low-cost, and low-energy synthesis, as already discussed earlier. In this section, the preparation of AAM catalysts and studies in which they have been used for wastewater treatment are outlined.

The preparation of AAM catalysts and catalyst supports is largely similar to the preparation of adsorbents (see Sect. 2.1) or porous materials (see Sect. 3.2). An example of mesoporous microstructure of an AAM catalyst is shown in Fig. 4. Catalytically active metals can be introduced to the structure by mixing them into the fresh-state AAM paste in the form of salts or nanoparticles or to the cured material via ion exchange either directly or by first converting the geopolymer into $\mathrm{NH}_{4}{ }^{+}$form (MacKenzie 2014). The advantage of carrying out the $\mathrm{Na}^{+}$to $\mathrm{NH}_{4}{ }^{+}$ion exchange step first is that the subsequent ion exchange with catalytically active metal is more efficient (Gasca-Tirado et al. 2012). Moreover, wet
University of Oulu (Finland); the Department of Industrial Engineering, University of Padova (Italy); and Kajaani University of Applied Sciences, Kajaani (Finland), respectively). Photograph credits Tero Luukkonen and Kimmo Kemppainen

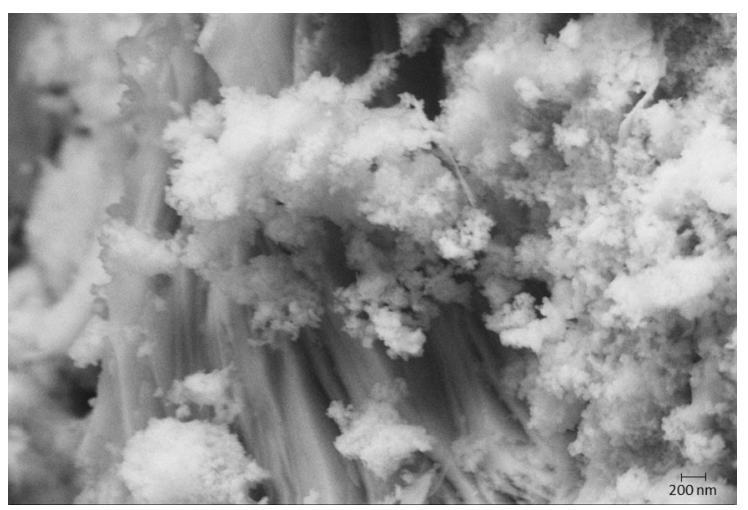

Fig. 4 Micrograph of a mesoporous AAM catalyst support prepared by mixing metakaolin and $\mathrm{KOH}$

and incipient wetness impregnation techniques have been used for the addition of catalytically active components to geopolymers. Furthermore, some waste-based raw materials can already contain catalytically active metals as in a study by Zhang and Liu (2013) in which fly ash was used as an AAM precursor. It already contained a sufficient amount of metal oxide semiconductors, $\mathrm{Fe}_{2} \mathrm{O}_{3}$ (4.78 weight-\%) and $\mathrm{TiO}_{2}$ (0.94 weight-\%), to provide photocatalytic activity for dye degradation (Zhang and Liu 2013).

The photocatalytic degradation of methyl orange was performed with $\mathrm{Cd}$ suspension geopolymer spheres (CdS-GS), which were prepared by the suspension-solidification method together with the photochemical synthesis process (i.e., the growth of $\mathrm{CdS}$ crystals was promoted by UV irradiation) ( $\mathrm{Li}$ et al. 2016a). The methyl orange solutions (concentration $5 \mathrm{mg} / \mathrm{L})$ were treated continuously $(0.4 \mathrm{~mL} /$ min) at $25^{\circ} \mathrm{C}$ in a quartz tube reactor packed with 
CdS-GS catalysts under UV light. Methyl orange could be removed up to $93 \%$ (39\% adsorption and $54 \%$ photo degradation) using a bed of $5 \mathrm{~g}$ of CdS-GS and $2 \mathrm{~h}$ contact time. Moreover, the resistance against catalyst poisoning was tested by repeating five cycles: the abatement of methyl orange was still over $90 \%$, indicating that the $\mathrm{CdS}$ geopolymer spheres had relatively stable photocatalytic performance.

Another dye, methylene blue, was photocatalytically degraded using geopolymers based on metakaolin (Gasca-Tirado et al. 2012; Fallah et al. 2015) or fly ash (Zhang and Liu 2013). Gasca-Tirado et al. (2012) incorporated the active component, $\mathrm{TiO}_{2}$, into the metakaolin-based geopolymers via ion exchange. The geopolymers treated with ion exchange had a larger surface area than those without the active component. The highest $\mathrm{Ti}$ content was achieved with the geopolymer cured at $90{ }^{\circ} \mathrm{C}$. After $90 \mathrm{~min}$ of reaction, the color of the methylene blue disappeared completely. Zhang and Liu (2013) used their fly ash-based photocatalyst (without addition of active metals) with a contact time of six hours and obtained $93 \%$ abatement of methylene blue. However, adsorption was responsible for $89 \%$ of the methylene blue removal. In the study of Fallah et al. (2015), most of the methylene blue degradation was also caused by adsorption of the dye onto the $\mathrm{Cu}_{2} \mathrm{O}$ nanoparticlemodified metakaolin-based geopolymer, and UVinduced degradation was a minor mechanism.

Zhang et al. (2017) prepared a composite material from alkali-activated bottom ash and graphene containing $\mathrm{Mn}^{2+}$ and $\mathrm{CuO}$ as active metals. Metals were introduced by performing first ion-exchange of $\mathrm{Na}^{+}$to $\mathrm{NH}_{4}{ }^{+}$and submerging the material into solutions of $\mathrm{Cu}\left(\mathrm{NO}_{3}\right)_{2} \cdot 3 \mathrm{H}_{2} \mathrm{O}$ and $\mathrm{Mn}\left(\mathrm{NO}_{3}\right)_{2}$. Then, calcination at $400{ }^{\circ} \mathrm{C}$ for $4 \mathrm{~h}$ was performed to convert copper into oxide. The catalyst was tested successfully for photocatalytic degradation of aqueous direct sky blue 5B dye and hydrogen gas production.

\section{Solidification/stabilization of wastewaters and water treatment residues}

Water and wastewater treatment processes produce various sludges, spent ion-exchangers, catalysts, and highly concentrated effluents, which pose frequently disposal problems due to the hazardous components and chemical instability. One option for treating these water treatment residues (WTR) is the solidification/ stabilization $(\mathrm{S} / \mathrm{S})$, which allows safe landfilling or utilizing obtained solid materials.

The definition of $\mathrm{S} / \mathrm{S}$ is the process of mixing waste with binder to convert it into a monolithic solid and thus reduce the likelihood of release of hazardous components to the environment (Bernal 2014). Typically, S/S mechanisms are divided into two categories: (1) physical encapsulation and (2) chemical stabilization. However, a clear-cut separation is not meaningful as these mechanisms can work in conjunction and the exact determination of mechanism is difficult (Glasser 1997). Furthermore, El-Eswed (2018) defined the immobilization of solid and liquid wastes into an AAM matrix as "intra-solidification" and "inter-solidification", respectively. Typically, AAMs are able to decrease the mobility of cationic species effectively, whereas transition metals, which form oxyanionic species, remain less effectively stabilized (Bernal et al. 2014a, b). Both solid and liquid WTR fractions have been immobilized into the AAM matrixes as illustrated in Fig. 5.

Physical encapsulation occurs on a micrometer scale. The zeolite-type cage structures can trap hazardous components if their size is suitable. Other types of physical encapsulation can take place when a physical barrier prevents the leaching medium (water) from contacting the hazardous components, thus preventing leaching.

Chemical stabilization occurs on the nanoscale. Metal(loid)s can react with other reactive compounds in the mixture and become part of the aluminosilicate structure, for example by replacing silicon atoms (Schoenung 2008). It was recently demonstrated that the immobilization of metals does not occur with ion exchange but rather through isomorphous substitution (Zheng et al. 2016), which is a major difference from the above-discussed application as adsorbents (see Sect. 3). Transition metals could also precipitate as non-soluble compounds (e.g., as hydroxide) (Bernal et al. 2014a, b) and subsequently become trapped inside the geopolymer.

The studies concerning the $\mathrm{S} / \mathrm{S}$ treatment of wastewaters (i.e., inter-solidification) have been mostly conducted with synthetic wastewaters (i.e., metal salts dissolved in water) (see Table 2). The S/S treatment method could also be potentially applied to extremely concentrated effluents such as reverse osmosis reject water (brine). Some water treatment 
Fig. 5 Schematic presentation solidification/ stabilization of

a concentrated wastewaters and $\mathbf{b}$ solid water treatment residues. The need for aluminosilicate in $\mathbf{b}$ is determined by the reactivity of the solid water treatment residue. Obtained alkaliactivated material can be safely disposed to landfill or utilized as, for instance, construction material. Photograph credits Simon A. Eugster and Tero Luukkonen
(A) Solidification/stabilization of concentrated wastewaters

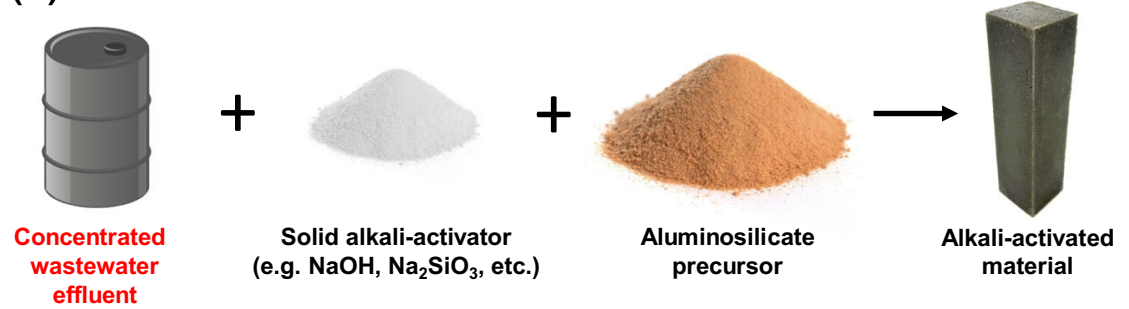

(B) Solidification/stabilization of solid water treatment residues

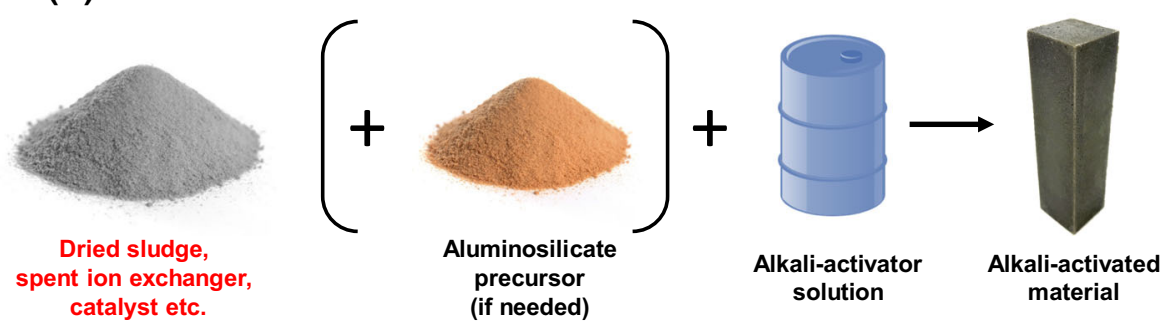

sludges, on the other hand, are suitable raw materials for AAMs as they contain alumina and/or silicate and the resulting products can be used as masonry units, for instance (Belmokhtar et al. 2016; Xu et al. 2013; Yang et al. 2009, 2010, 2013a, b; Guo and Shi 2012; Antunes Boca Santa et al. 2013; Chen et al. 2009, 2011; Choi et al. 2010; Yan et al. 2016; Nimwinya et al. 2016; Poowancum et al. 2015; Suksiripattanapong et al. 2015a, b, c; Horpibulsuk et al. 2015).

Table 2 compiles studies related to S/S of wastewater and solid WTRs. Studies in which hazardous components were added as solid are excluded from this survey, whereas the studies discussing $\mathrm{S} / \mathrm{S}$ of WTRs, wastewaters, or synthetic wastewaters (i.e., model solutions) are included. As can be seen, most studies have used synthetic wastewater, such as lead and copper nitrates dissolved in water, to simulate immobilization of wastewater into AAMs. The suggested stabilization mechanism for most heavy metals is a combination of physical encapsulation, chemical bonding, and/or charge balancing of the negative aluminate group. The immobilization efficiency was not typically reported, although there are numerous suitable leaching procedures as described in Sect. 7. Sullivan et al. (2010) reviewed arsenic-containing water treatment waste disposal methods and suggested alkali-activation/geopolymerization as a potential approach, although no published studies were available.

\section{Leaching tests and regulatory guidelines}

As the primary goal of $\mathrm{S} / \mathrm{S}$ is to reduce the release of contaminants into the environment, chemical leaching tests provide the most useful information regarding the successfulness of S/S treatments. Experimental conditions such as $\mathrm{pH}$, type and amount of leachant, leaching time, and particle size of the studied material affect the concentration of contaminants in the leachate. Consequently, the purpose of this section is to provide a general overview of the regulatory requirements for stabilized materials and introduce some of the most commonly used leaching tests.

Leaching tests can be roughly divided into three groups: (1) regulatory tests, (2) predictive tests, and (3) investigatory tests (LaGrega et al. 1994). The first group of tests are used in regulatory decision-making processes, where the result of the test is compared to the limit values determined by the authorities. Predictive tests are used for modeling real-world contaminant migration in the long term. Investigatory tests are used to study the binding mechanisms of contaminants.

\section{European leaching limits for landfilling}

According to the European waste hierarchy, landfilling is the least preferable option for waste management (European Council 2008). However, where landfilling of waste is required, it is regulated with the Landfill Directive (European Council1999), which 


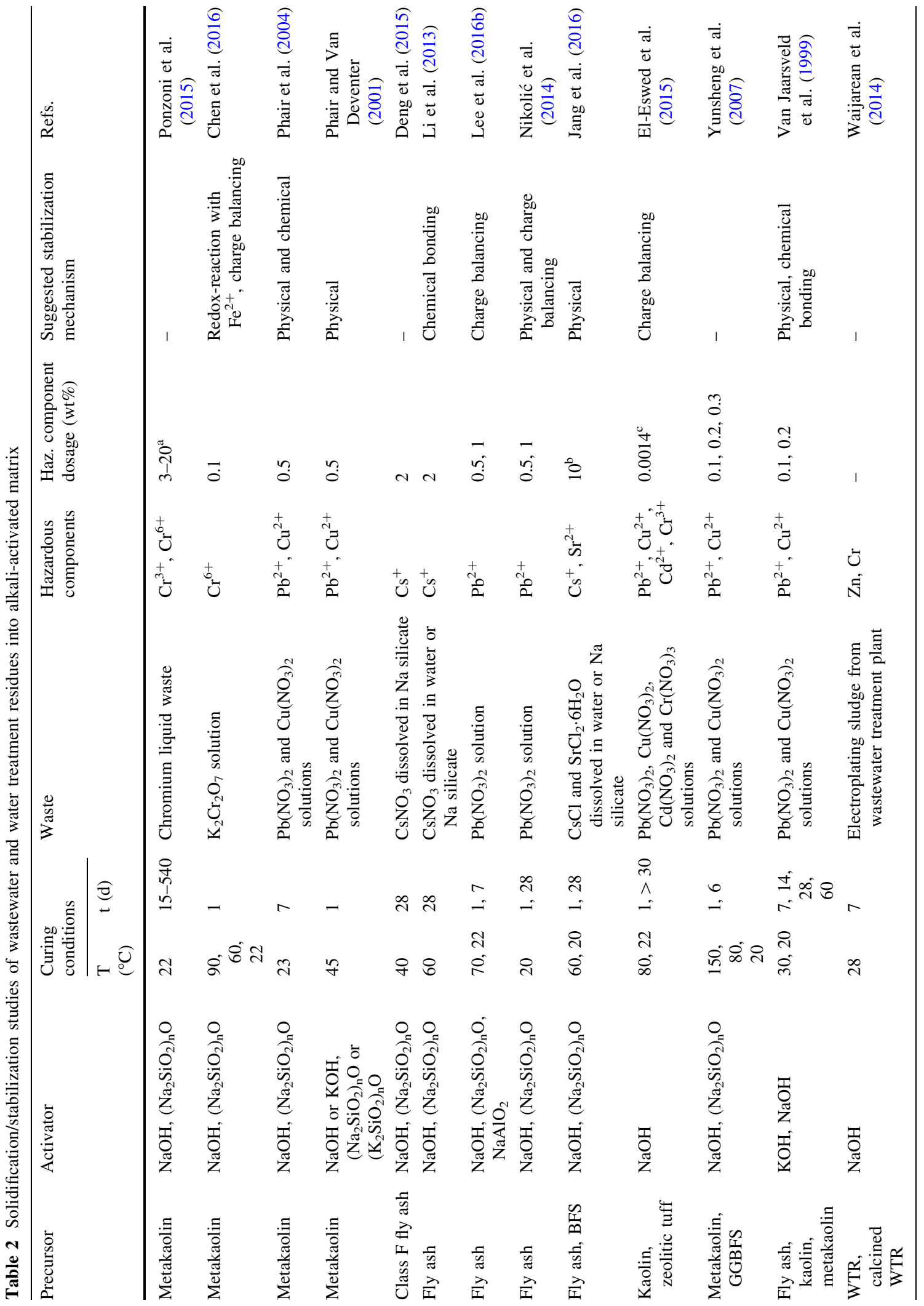




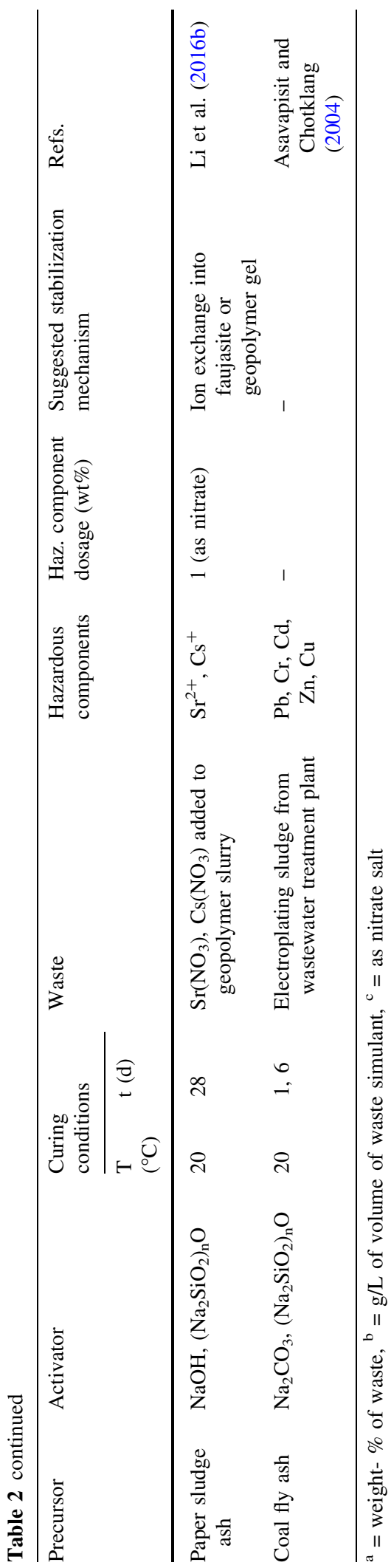

defines different waste categories (municipal waste, hazardous waste, non-hazardous waste, and inert waste) and landfill types (inert waste, non-hazardous waste, and hazardous waste). Exact criteria for different waste classes and landfill types are given in the 2003/33/EC (European Council 2003). Leaching limit values for the different types of landfills are given in Table 3. Leaching of different components must be determined using either standards EN 12457/1-4 (EN 12457-1 2002; EN 12457-2 2002; EN 12457-3 2002; EN 12457-4 2002) or CEN/TS 14405 (2004). Member states can determine which of the test methods and corresponding limit values should be used.

Regulatory leaching tests

The four-part EN 12457 standard is a compliance tests used to determine whether the waste complies with specific reference values (see Table 3 ). The tests include one or two extraction batches on different $\mathrm{L} / \mathrm{S}$ ratios (2-10) and different particle sizes $(<4$ or $<10$ $\mathrm{mm}$ ). In all phases, a sample is shaken with distilled water for a total of $24 \mathrm{~h}$. These tests have also been used for AAM samples (Kourti et al. 2011; Pereira et al. 2009; Izquierdo et al. 2009, 2010; Lancellotti et al. 2010; Galiano et al. 2011; Ogundiran et al. 2013; Onisei et al. 2012; Nikolić et al. 2013).

Percolation test CEN/TS 14405 (2004) is used to study the leaching of inorganic constituents from granular wastes. The studied sample (particle size $<4 \mathrm{~mm}$ or $<10 \mathrm{~mm}$ ) is packed into a column and demineralized water is percolated through it $(15 \pm 2 \mathrm{~cm} /$ day). Samples from the eluate are collected with cumulative $\mathrm{L} / \mathrm{S}$ ratios of $0.1,0.2,0.5,1.0$, 2.0, 5.0, and 10.0.

United States Environmental Protection Agency method EPA 1311 (Toxicity Characteristic Leaching Procedure, TCLP) is meant to study the leaching of both organic and inorganic analytes present in liquid, solid, and multiphasic wastes (SW-846 Test Method 1311 1992). Liquid wastes are filtered and the extract is analyzed. Solid wastes (particle size $<9.5 \mathrm{~mm}$ ) are agitated with extraction fluid for $18 \mathrm{~h}(\mathrm{~L} / \mathrm{S}=20)$. The extraction fluid is an aqueous solution of either acid ( $\mathrm{pH} 2.88$ ) or acid and $\mathrm{NaOH}$ ( $\mathrm{pH} 4.93$ ). This test has been widely used for AAM samples (Galiano et al. 2011; Nikolić et al. 2013; Ogundiran et al. 2013; Onisei et al. 2012; Pereira et al. 2009; Fernández- 
Table 3 Leaching limit values for different types of landfills according to the European Council Decision 2003/33/EC (2003)

\begin{tabular}{|c|c|c|c|c|c|c|c|c|c|}
\hline \multirow[t]{2}{*}{ Component } & \multicolumn{3}{|c|}{ Inert waste } & \multicolumn{3}{|c|}{$\begin{array}{l}\text { Non-hazardous waste/Hazardous } \\
\text { waste acceptable at non-hazardous } \\
\text { waste landfill }\end{array}$} & \multicolumn{3}{|c|}{ Hazardous waste } \\
\hline & $\begin{array}{l}\mathrm{L} / \mathrm{S}=2 \\
\mathrm{~L} / \mathrm{kg} \\
\mathrm{mg} / \mathrm{kg} \mathrm{dry}\end{array}$ & $\begin{array}{l}\mathrm{L} / \mathrm{S}=10 \\
\mathrm{~L} / \mathrm{kg} \\
\text { substance }\end{array}$ & $\begin{array}{l}\mathrm{C}_{0} \\
\text { (percolation } \\
\text { test) } \\
\mathrm{mg} / \mathrm{L}\end{array}$ & $\begin{array}{l}\mathrm{L} / \mathrm{S}=2 \\
\mathrm{~L} / \mathrm{kg} \\
\mathrm{mg} / \mathrm{kg} \text { dry }\end{array}$ & $\begin{array}{l}\mathrm{L} / \mathrm{S}=10 \\
\mathrm{~L} / \mathrm{kg} \\
\text { substance }\end{array}$ & $\begin{array}{l}\mathrm{C}_{0} \\
\text { (percolation } \\
\text { test) } \\
\mathrm{mg} / \mathrm{L}\end{array}$ & $\begin{array}{l}\mathrm{L} / \mathrm{S}=2 \\
\mathrm{~L} / \mathrm{kg} \\
\mathrm{mg} / \mathrm{kg} \text { dry }\end{array}$ & $\begin{array}{l}\mathrm{L} / \mathrm{S}=10 \\
\mathrm{~L} / \mathrm{kg} \\
\text { substance }\end{array}$ & $\begin{array}{l}\mathrm{C}_{0} \\
\text { (percolation } \\
\text { test) } \\
\mathrm{mg} / \mathrm{L}\end{array}$ \\
\hline As & 0.1 & 0.5 & 0.06 & 0.4 & 2 & 0.3 & 6 & 25 & 3 \\
\hline $\mathrm{Ba}$ & 7 & 20 & 4 & 30 & 100 & 20 & 100 & 300 & 60 \\
\hline $\mathrm{Cd}$ & 0.03 & 0.04 & 0.02 & 0.6 & 1 & 0.3 & 3 & 5 & 1.7 \\
\hline Cr total & 0.2 & 0.5 & 0.1 & 4 & 10 & 2.5 & 25 & 70 & 15 \\
\hline $\mathrm{Cu}$ & 0.9 & 2 & 0.6 & 25 & 50 & 30 & 50 & 100 & 60 \\
\hline $\mathrm{Hg}$ & 0.003 & 0.01 & 0.002 & 0.05 & 0.2 & 0.03 & 0.5 & 2 & 0.3 \\
\hline Mo & 0.3 & 0.5 & 0.2 & 5 & 10 & 3.5 & 20 & 30 & 10 \\
\hline $\mathrm{Ni}$ & 0.2 & 0.4 & 0.12 & 5 & 10 & 3 & 20 & 40 & 12 \\
\hline $\mathrm{Pb}$ & 0.2 & 0.5 & 0.15 & 5 & 10 & 3 & 25 & 50 & 15 \\
\hline $\mathrm{Sb}$ & 0.02 & 0.06 & 0.1 & 0.2 & 0.7 & 0.15 & 2 & 5 & 1 \\
\hline $\mathrm{Se}$ & 0.06 & 0.1 & 0.04 & 0.3 & 0.5 & 0.2 & 4 & 7 & 3 \\
\hline $\mathrm{Zn}$ & 2 & 4 & 1.2 & 25 & 50 & 15 & 90 & 200 & 60 \\
\hline $\mathrm{Cl}^{-}$ & 550 & 800 & 460 & 10,000 & 15,000 & 8500 & 17,000 & 25,000 & 15,000 \\
\hline $\mathrm{F}^{-}$ & 4 & 10 & 2.5 & 60 & 150 & 40 & 200 & 500 & 120 \\
\hline $\mathrm{SO}_{4}{ }^{2-}$ & $560^{\mathrm{a}}$ & $1000^{\mathrm{a}}$ & 1500 & 10,000 & 20,000 & 7000 & 25,000 & 50,000 & 17,000 \\
\hline $\begin{array}{r}\text { Phenol } \\
\text { index }\end{array}$ & 0.5 & 500 & 0.3 & - & - & - & - & - & - \\
\hline $\mathrm{DOC}^{\mathrm{b}}$ & 240 & 1 & 160 & 380 & 800 & 250 & 480 & 1000 & 320 \\
\hline $\mathrm{TDS}^{\mathrm{c}}$ & 2500 & 4000 & - & 40,000 & 60,000 & - & 70,000 & 100,000 & - \\
\hline
\end{tabular}

${ }^{a}$ If the these values are not met, alternative requirements are: $1500 \mathrm{mg} / \mathrm{L}$ as $\mathrm{C}_{0}$ at $\mathrm{L} / \mathrm{S}=0,1 \mathrm{~L} / \mathrm{kg}$ (percolation test) and $6000 \mathrm{mg} / \mathrm{kg}$ at $\mathrm{L} / \mathrm{S}=10 \mathrm{~L} / \mathrm{kg}$ (batch leaching or percolation test)

${ }^{\mathrm{b}}$ If these values are not met (at $\mathrm{pH}$ of waste), alternative testing conditions are $\mathrm{L} / \mathrm{S}=10 \mathrm{~L} / \mathrm{kg}$ and a $\mathrm{pH}$ between 7.5 and 8.0 : the results should be $\leq 500 \mathrm{mg} / \mathrm{kg}$ (inert waste) or $\leq 800 \mathrm{mg} / \mathrm{kg}$ (non-hazardous waste and hazardous waste)

${ }^{\mathrm{c}}$ The values for total dissolved solids (TDS) can be used alternatively to the values for sulfate and chloride

Jiménez et al. 2005; Bankowski et al. 2004a, b; Kumar and Kumar 2013; Phair et al. 2004).

Other tests that can be applied for AAMs include batch tests EPA 1313 (SW-846 Test Method 1313) and EPA 1312 (SW-846 Test Method 1312 1994). The first is used to study the leaching of inorganic constituents as a function of $\mathrm{pH}$ and the latter (The Synthetic Precipitation Leaching Procedure, SPLP) is similar to the TCLP test (SW-846 Test Method 1311 1992) but the extraction fluids are different (mixture of sulfuric and nitric acids; $\mathrm{pH} 4.2$ or 5.0). Diffusion tests ANS 16.1 (2008) and MCC-1 (1981), also usable for AAMs, were originally designed for nuclear wastes. Finally, batch leaching test NEN 7341 (1995) is used to measure the maximum solubility of harmful substances from granulated waste material.

Predictive leaching tests

Diffusion test NEN 7345 (1995) has been used especially in Europe to study the solubility of waste materials. However, this test has been replaced with static diffusion test NEN 7375 (2004), which is used to simulate the leaching of inorganic components into water from monolithic materials under aerobic conditions as a function of time. With this test, it is possible to determine the leaching mechanism (diffusion, dissolution, depletion, or surface wash-off) of 
inorganic components. In the test, solid cubic mortar samples are subjected to leaching in closed tanks using deionized water as the leachant. The water is replaced eight times during the test (at 0.25, 1, 2.25, 6, 9, 16, 35, and 65 days). The eluates are filtered, and the filtrates are analyzed. These standards have been used in some studies for geopolymer samples (Pereira et al. 2009; Izquierdo et al. 2010; Ogundiran et al. 2013; ÁlvarezAyuso et al. 2008).

\section{Investigatory leaching tests}

There are several sequential leaching methods in the literature, but the two most widely used are the Tessier et al. (1979) method and BCR (Rauret et al. 1999) method. In sequential leaching, various types of chemical reagents are applied to the samples in a series, with each successive treatment being more drastic than the previous one. Typical fractions of sequential leaching are (1) a water-soluble fraction, (2) an acid-soluble fraction, (3) a reducible fraction, and (4) an oxidizable fraction. In theory, the first fraction should contain water-soluble ions, while the second fraction should contain metals bonded electrostatically, metals bonded with weak covalent bonds, or metals bonded to carbonates. The third fraction should contain metals bonded to $\mathrm{Mn}$ and Fe oxides, while the fourth fraction should contain metals bonded to organic matter or to different sulfides and oxides. However, sequential leaching was originally designed for fractionating sediments. Therefore, the bonding of different metals that originate from matrixes that differ notably from sediments, such as geopolymers, cannot be precisely deduced from sequential extraction results. Still, even when the bonding of metals cannot be deduced from sequential extraction data, it nevertheless provides a good estimate of the solubility of metals in real environmental conditions. Sequential leaching has been used for geopolymer samples (Yliniemi et al. 2015; Pesonen et al. 2016).

\section{Conclusions}

The amount of studies about water and wastewater treatment with alkali-activated materials (AAMs) has significantly increased during the last decade. One of the main drivers for this interest is that AAMs have many beneficial characteristics (e.g., mechanical strength, durability, porosity, and ion-exchange capacity) similar to competing materials (e.g., conventional ceramics, synthetic zeolites, or organic polymers) but the preparation process is simple and low-energy. Moreover, AAMs can be prepared of several industrial by-products, which makes them consistent with the circular economy.

As adsorbents or ion-exchangers, AAMs have shown promising potential for the removal and possible recovery of different metal(loid)s, rare earth elements, ammonium, sulfate, and organic dyes. Studies related to the use of AAMs as catalysts or catalyst supports indicate that these materials have a great potential for photocatalytic degradation of recalcitrant organic compounds (micropollutants). AAM-based membranes utilize the intrinsic mesoporosity of the materials and thus could be used in micro or ultrafiltration applications. However, if larger pore sizes are generated, AAMs can be used as lower pressure filtration media as well. The ability of AAMs to solidify/stabilize various potentially toxic elements can be taken advantage of in the management and utilization of water treatment residues such as sludges and spent adsorbents. Some other innovative uses for AAMs in water treatment include $\mathrm{pH}$ buffering materials, antimicrobial materials, and carrier media for biological treatment processes. As a final remark, it can be concluded that although the performance in the reviewed applications is promising, more research is needed in larger scale and longer duration to demonstrate the technological readiness of these materials.

Acknowledgements Open access funding provided by University of Oulu including Oulu University Hospital. This work was supported by the Finnish Funding Agency for Technology and Innovation (TEKES) [Grant Number 4096/31/2014] (Project GeoSorbents).

Open Access This article is distributed under the terms of the Creative Commons Attribution 4.0 International License (http:// creativecommons.org/licenses/by/4.0/), which permits unrestricted use, distribution, and reproduction in any medium, provided you give appropriate credit to the original author(s) and the source, provide a link to the Creative Commons license, and indicate if changes were made.

\section{References}

Adak D, Sarkar M, Maiti M, Tamang A, Mandal S, Chattopadhyay B (2015) Anti-microbial efficiency of nano 
silver-silica modified geopolymer mortar for eco-friendly green construction technology. RSC Adv 5:64037-64045

Akhigbe L, Ouki S, Saroj D, Lim XM (2014) Silver-modified clinoptilolite for the removal of Escherichia coli and heavy metals from aqueous solutions. Environ Sci Pollut Res 21:10940-10948

Al-Harahsheh MS, Al Zboon K, Al-Makhadmeh L, Hararah M, Mahasneh M (2015) Fly ash based geopolymer for heavy metal removal: a case study on copper removal. J Environ Chem Eng 3:1669-1677

Alshaaer M, Slatyi F, Khoury H, Rahier H, Wastiels J (2010) Development of low-cost functional geopolymeric materials. In: Fox K, Hoffman E, Manjooran N, Pickrell G (eds) Advances for materials science for environmental and nuclear technology. Wiley, Hoboken, pp 159-168

Alshaaer M, El-Eswed B, Yousef RI, Khalili F, Rahier H (2012) Development of functional geopolymers for water purification, and construction purposes. J Saudi Chem Soc 20:S85-S92

Alshaaer M, Zaharaki D, Komnitsas K (2014) Microstructural characteristics and adsorption potential of a zeolitic tuffmetakaolin geopolymer. Desalin Water Treat 56:338-345

Álvarez-Ayuso E, Querol X, Plana F, Alastuey A, Moreno N, Izquierdo M, Font O, Moreno T, Diez S, Vázquez E (2008) Environmental, physical and structural characterisation of geopolymer matrixes synthesised from coal (co-) combustion fly ashes. J Hazard Mater 154:175-183

Al-Zboon K, Al-Harahsheh MS, Hani FB (2011) Fly ash-based geopolymer for $\mathrm{Pb}$ removal from aqueous solution. J Hazard Mater 188:414-421

Al-Zboon K, Al-smadi BM, Al-Khawaldh S (2016) Natural volcanic tuff-based geopolymer for $\mathrm{Zn}$ removal: adsorption isotherm, kinetic, and thermodynamic study. Water Air Soil Pollut 227:1-22

Andrejkovicová S, Sudagar A, Rocha J, Patinha C, Hajjaji W, Da Silva EF, Velosa A, Rocha F (2016) The effect of natural zeolite on microstructure, mechanical and heavy metals adsorption properties of metakaolin based geopolymers. Appl Clay Sci 126:141-152

ANSI/ANS-16.1-2003, R2008 (2008) Measurement of the leachability of solidified low-level radioactive wastes by a short-term test procedure. American National Standards Institute

Antunes Boca Santa RA, Bernardin AM, Riella HG, Kuhnen NC (2013) Geopolymer synthetized from bottom coal ash and calcined paper sludge. J Clean Prod 57:302-307

Ariffin N, Abdullah MMAB, Zainol MRRMA, Murshed MF, Hariz-Zain, Faris MA, Bayuaji R (2017) Review on adsorption of heavy metal in wastewater by using geopolymer. MATEC Web Conf 97

Asavapisit S, Chotklang D (2004) Solidification of electroplating sludge using alkali-activated pulverized fuel ash as cementitious binder. Cem Concr Res 34:349-353

Ascensão G, Seabra MP, Aguiar JB, Labrincha JA (2017) Red mud-based geopolymers with tailored alkali diffusion properties and $\mathrm{pH}$ buffering ability. J Clean Prod 148:23-30

Asim N, Alghoul M, Mohammad M, Amin MH, Akhtaruzzaman M, Amin N, Sopian K (2019) Emerging sustainable solutions for depollution: geopolymers. Constr Build Mater 199:540-548
Bai C, Colombo P (2017) High-porosity geopolymer membrane supports by peroxide route with the addition of egg white as surfactant. Ceram Int 43:2267-2273

Bai C, Colombo P (2018) Processing, properties and applications of highly porous geopolymers: a review. Ceram Int 44:16103-16118

Bai C, Franchin G, Elsayed H, Conte A, Colombo P (2016) High strength metakaolin-based geopolymer foams with variable macroporous structure. J Eur Ceram Soc 36:4243-4249

Bai C, Franchin G, Elsayed H, Zaggia A, Conte L, L. H, Colombo P (2017) High-porosity geopolymer foams with tailored porosity for thermal insulation and wastewater treatment. J Mater Res (in press)

Bankowski P, Zou L, Hodges R (2004a) Reduction of metal leaching in brown coal fly ash using geopolymers. J Hazard Mater 114:59-67

Bankowski P, Zou L, Hodges R (2004b) Using inorganic polymer to reduce leach rates of metals from brown coal fly ash. Miner Eng 17:159-166

Barbosa VFF, MacKenzie KJD, Thaumaturgo C (2000) Synthesis and characterisation of materials based on inorganic polymers of alumina and silica: sodium polysialate polymers. Int J Inorg Mat 2:309-317

Barbosa TR, Foletto EL, Dotto GL, Jahn SL (2018) Preparation of mesoporous geopolymer using metakaolin and rice husk ash as synthesis precursors and its use as potential adsorbent to remove organic dye from aqueous solutions 44:416-423

Bell JL, Kriven WM (2010) Formation of an iron-based inorganic polymer (geopolymer). Ceram Eng Sci Proc 30:301-312

Belmokhtar N, Ben Allal L, Lamrani S (2016) Effect of $\mathrm{Na}_{2}$ $\mathrm{SiO}_{3} / \mathrm{NaOH}$ mass ratio on the development of structure of an industrial waste-based geopolymer. J Mater Environ Sci $7: 390-396$

Bernal S (2014) Other potential applications for alkali-activated materials. In: Provis J, van Deventer J (eds) Alkali activated materials-state-of-the art report, RILEM TC 224-AAM. Springer, Dordcrecht, pp 355-360

Bernal SA, Provis JL, Fernández-Jiménez A, Krivenko PV, Kavalerova E, Palacios M, Shi C (2014a) Binder chemistry - High-calcium alkali-activated materials. In: Provis JL, Van Deventer JSJ (eds) Alkali activated materials, state-ofthe-art report, RILEM TC 224-AAM. Springer, Dordrecht, pp 59-91

Bernal SA, San Nicolas R, Myers RJ, Mejía De Gutiérrez R, Puertas F, van Deventer JSJ, Provis JL (2014b) MgO content of slag controls phase evolution and structural changes induced by accelerated carbonation in alkali-activated binders. Cem Concr Res 57:33-43

Bortnovsky O, Dedecek J, Tvaružková Z, Sobalík Z, Šubrt J (2008) Metal ions as probes for characterization of geopolymer materials. J Am Ceram Soc 91:3052-3057

Bumanis G (2015) The effect of alkaline material particle size on adjustment ability of buffer capacity. Mater Sci 21:405-409

Bumanis G, Bajare D (2014) The effect of porous alkali activated material composition on buffer capacity in bioreactors. Int J Chem Mol Nucl Mat Metall Eng 8:1141-1147 
CEN/TS 14405:2004 (2004) Characterization of wasteleaching behaviour tests - up-flow percolation test (under specified conditions). European Committee for Standardization

Chen J, Huang J, Chang Y (2009) A preliminary study of reservoir sludge as a raw material of inorganic polymers. Constr Build Mater 23:3264-3269

Chen J, Huang J, Chang Y (2011) Use of reservoir sludge as a partial replacement of metakaolin in the production of geopolymers. Cem Concr Compos 33:602-610

Chen YL, Tong YY, Pan RW, Tang J (2013) The research on adsorption behaviors and mechanisms of geopolymers on $\mathrm{Sr}^{2+}, \mathrm{Co}^{2+}$ and $\mathrm{Cs}^{+1,2}$. Adv Mater Res 704:313-318

Chen J, Wang Y, Wang H, Zhou S, Wu H, Lei X (2016) Detoxification/immobilization of hexavalent chromium using metakaolin-based geopolymer coupled with ferrous chloride. J Environ Chem Eng 4:2084-2089

Cheng TW, Lee ML, Ko MS, Ueng TH, Yang SF (2012) The heavy metal adsorption characteristics on metakaolinbased geopolymer. Appl Clay Sci 56:90-96

Choi SJ, Jun SS, Oh JE, Monteiro PJM (2010) Properties of alkali-activated systems with stone powder sludge. J Mater Cycles Waste Manage 12:275-282

Chowdhury S, Mazumder MAJ, Al-Attas O, Husain T (2016) Heavy metals in drinking water: occurrences, implications, and future needs in developing countries. Sci Total Environ 569-570:476-488

Chuang L, Liao C (2015) Sorption of cesium using KZnFc on phosphoric acid-based geopolymer. Ceramics - Silikáty 59:125-134

Cilla MS, de Mello Innocentini MD, Morelli MR, Colombo P (2017) Geopolymer foams obtained by the saponification/ peroxide/gelcasting combined route using different soap foam precursors. J Am Ceram Soc 100:3440-3450

Ciora RJ, Liu PKT (2003) Ceramic membranes for environmental related applications. Fluid Part Sep J 15:51-60

Couto RSDP, Oliveira AF, Guarino AWS, Perez DV, Marques MRDC (2016) Removal of ammonia nitrogen from distilled old landfill leachate by adsorption on raw and modified aluminosilicate. Environ Technol 38:816-826

Cui J, Zhang X, Liu H, Liu S, Yeung KL (2008) Preparation and application of zeolite/ceramic microfiltration membranes for treatment of oil contaminated water. J Membr Sci 325:420-426

De la Rosa-Gómez I, Olguín MT, Alcántara D (2008a) Antibacterial behavior of silver-modified clinoptiloliteheulandite rich tuff on coliform microorganisms from wastewater in a column system. J Environ Manage 88:853-863

De la Rosa-Gómez I, Olguín MT, Alcántara D (2008b) Bactericides of coliform microorganisms from wastewater using silver-clinoptilolite rich tuffs. Appl Clay Sci 40:45-53

De La Torre ML, Grande JA, Graiño J, Gómez T, Cerón JC (2011) Characterization of AMD pollution in the River Tinto (SW Spain). Geochemical comparison between generating source and receiving environment. Water Air Soil Pollut 216:3-19

Deng N, An H, Cui H, Pan Y, Wang B, Mao L, Zhai J (2015) Effects of gamma-ray irradiation on leaching of simulated $133 \mathrm{Cs}$ radionuclides from geopolymer wasteforms. J Nucl Mater 459:270-275
Dolic MB, Rajakovic-Ognjanovic VN, Štrbac SB, Rakocevic ZL, Veljovic DN, Dimitrijevic SI, Rajakovic LV (2015) The antimicrobial efficiency of silver activated sorbents. Appl Surf Sci 357:819-831

Duan P, Yan C, Zhou W, Ren D (2016) Development of fly ash and iron ore tailing based porous geopolymer for removal of $\mathrm{Cu}$ (II) from wastewater. Ceram Int 42:13507-13518

Duxson P, Fernández-Jiménez A, Provis JL, Lukey GC, Palomo A, Van Deventer JSJ (2007) Geopolymer technology: the current state of the art. J Mater Sci 42:2917-2933

El-Eswed BI (2018) Solidification versus adsorption for immobilization of pollutants in geopolymeric materials: a review. In: Ares AE (ed) Solidification. IntechOpen, London

El-Eswed B, Alshaaer M, Yousef RI, Hamadneh I, Khalili F (2012) Adsorption of $\mathrm{Cu}$ (II), Ni (II), Zn (II), Cd (II) and $\mathrm{Pb}$ (II) onto kaolin/zeolite based-geopolymers. Adv Mater Phys Chem 2:119-125

El-Eswed B, Yousef R, Alshaaer M, Hamadneh I, Al-Gharabli S, Khalili F (2015) Stabilization/solidification of heavy metals in kaolin/zeolite based geopolymers. Int J Miner Process 137:34-42

EN 12457-1 (2002) Characterisation of waste. Leaching. Compliance test for leaching of granular waste materials and sludges. One stage batch test at a liquid to solid ratio of $21 / \mathrm{kg}$ for materials with high solid content and with particle size below $4 \mathrm{~mm}$ (without or with size reduction). European Committee for Standardization

EN 12457-2 (2002) Characterisation of Waste. Leaching. Compliance Test for leaching of granular waste materials and sludges. Part 2: One Stage Batch Test at a Liquid to Solid Ratio of $101 / \mathrm{kg}$ for Materials with Particle Size Below $4 \mathrm{~mm}$ (without Or with Size Reduction). European Committee for Standardization

EN 12457-3 (2002) Characterisation of waste. Leaching. Compliance test for leaching of granular waste materials and sludges. Two stage batch test at a liquid to solid ratio of $21 / \mathrm{kg}$ and $81 / \mathrm{kg}$ for materials with a high solid content and with a particle size below $4 \mathrm{~mm}$ (without or with size reduction). European Committee for Standardization

EN 12457-4 (2002) Characterisation of Waste. Leaching. Compliance test for leaching of granular waste materials and sludges. Part 4: One Stage Batch Test at a Liquid to Solid Ratio of $101 / \mathrm{kg}$ for Materials with Particle Size Below 10 mm (without Or with Size Reduction). European Committee for Standardization

European Council (1999) Council directive 1999/31/EC of 26 April 1999 on the landfill of waste. Off J Eur Union L182:1-19

European Council (2003) Council decision of 19 December 2002 establishing criteria and procedures for the acceptance of waste at landfills pursuant to Article 16 of and Annex II to Directive 1999/31/EC. Off J Eur Union L11:27-49

European Council (2008) Directive 2008/98/EC of the European parliament and of the council of 19 November 2008 on waste and repealing certain directives. Off J Eur Union $1: 3-30$

Fallah M, MacKenzie KJD, Hanna JV, Page SJ (2015) Novel photoactive inorganic polymer composites of inorganic 
polymers with copper(I) oxide nanoparticles. J Mater Sci 50:7374-7383

Fernández-Jiménez A, Palomo A, Macphee DE, Lachowski EE (2005) Fixing arsenic in alkali-activated cementitious matrices. J Am Ceram Soc 88:1122-1126

Fiket Ž, Galović A, Medunić G, Turk MF, Ivanić M, Dolenec M, Biljan I, Šoster A, Kniewald G (2018) Adsorption of rare earth elements from aqueous solutions using geopolymers. In: Proceedings, vol 2, 2-6

Galiano YL, Pereira CF, Vale J (2011) Stabilization/solidification of a municipal solid waste incineration residue using fly ash-based geopolymers. J Hazard Mater 185:373-381

Gao K, Lin KL, Wang D, Hwang CL, Shiu HS, Chang YM, Cheng TW (2014) Effects $\mathrm{SiO}_{2} / \mathrm{Na}_{2} \mathrm{O}$ molar ratio on mechanical properties and the microstructure of nano- $\mathrm{SiO}_{2}$ metakaolin-based geopolymers. Constr Build Mater 53:503-510

García-Lodeiro I, Fernández-Jiménez A, Palomo A, MacPhee DE (2010) Effect of calcium additions on N-A-S-H cementitious gels. J Am Ceram Soc 93:1934-1940

García-Lodeiro I, Fernández-Jiménez A, Palomo A (2013) Variation in hybrid cements over time. alkaline activation of fly ash-portland cement blends. Cem Concr Res 52:112-122

Gasca-Tirado JR, Manzano-Ramírez A, Villaseñor-Mora C, Muñiz-Villarreal MS, Zaldivar-Cadena AA, Rubio-Ávalos JC, Borrás VA, Mendoza RN (2012) Incorporation of photoactive $\mathrm{TiO}_{2}$ in an aluminosilicate inorganic polymer by ion exchange. Microporous Mesoporous Mater 153:282-287

Ge Y, Yuan Y, Wang K, He Y, Cui X (2015a) Preparation of geopolymer-based inorganic membrane for removing $\mathrm{Ni}^{2+}$ from wastewater. J Hazard Mater 299:711-718

Ge Y, Cui X, Kong Y, Li Z, He Y, Zhou Q (2015b) Porous geopolymeric spheres for removal of $\mathrm{Cu}$ (II) from aqueous solution: synthesis and evaluation. J Hazard Mater 283:244-251

Ge Y, Cui X, Liao C, Li Z (2017) Facile fabrication of green geopolymer/alginate hybrid spheres for efficient removal of $\mathrm{Cu}$ (II) in water: batch and column studies. Chem Eng J 311:126-134

Glad BE, Kriven WM (2013) Optimization of gas adsorption porosimetry for geopolymer analysis. J Am Ceram Soc 96:3643-3649

Glasser F (1997) Fundamental aspects of cement solidification and stabilisation. J Hazard Mater 52:151-170

Glukhovsky VD (1959) Soil silicates. Gostroiizdat Publish, Kiev, USSR

Granizo ML, Blanco-Varela MT, Martínez-Ramírez S (2007) Alkali activation of metakaolins: Parameters affecting mechanical, structural and microstructural properties. J Mater Sci 42:2934-2943

Guillén FJ, Baeza A, Salas A (2010) Strontium. In: Atwood DA (ed) Radionuclides in the environment. Wiley, Chichester, pp 79-96

Guo X, Shi H (2012) Performances and mechanism of geopolymers prepared from thermally-treated sludge and high-calcium fly ash. Tongji Daxue Xuebao 40:1229-1233

Guo X, Shi H (2017) Microstructure and heavy metal adsorption mechanisms of hydrothermally synthesized Al-substituted tobermorite. Mater Struct 50:245
Hamaideh A, Al-Qarallah B, Hamdi MR, Mallouh SAA, Alshaaer M (2014) Synthesis of geopolymers using local resources for construction and water purification. J Water Res Prot 6:507-513

Hashimoto S, MacHino T, Takeda H, Daiko Y, Honda S, Iwamoto Y (2015) Antimicrobial activity of geopolymers ionexchanged with copper ions. Ceram Int 41:13788-13792

He Y, Cui XM, Liu XD, Wang YP, Zhang J, Liu K (2013) Preparation of self-supporting NaA zeolite membranes using geopolymers. J Membr Sci 447:66-72

He H, Xu S, Han R, Wang Q (2016) Nutrient sequestration from wastewater by using zeolite Na-P1 synthesized from coal fly ash. Environ Technol 38:1022-1029

Hedström A (2001) Ion exchange of ammonium in zeolites: a literature review. J Environ Eng 127:673-681

Horpibulsuk S, Suksiripattanapong C, Samingthong W, Rachan R, Arulrajah A (2015) Durability against wetting-drying cycles of water treatment sludge-fly ash geopolymer and water treatment sludge-cement and silty clay-cement systems. J Mater Civ Eng 28:04015078

Huang Y, Han M, Yi R (2012) Microstructure and properties of fly ash-based geopolymeric material with $5 \mathrm{~A}$ zeolite as a filler. Constr Build Mater 33:84-89

International Atomic Energy Agency (2014) The environmental behaviour of radium Technical reports series no. 476

Izquierdo M, Querol X, Davidovits J, Antenucci D, Nugteren H, Fernández-Pereira C (2009) Coal fly ash-slag-based geopolymers: microstructure and metal leaching. J Hazard Mater 166:561-566

Izquierdo M, Querol X, Phillipart C, Antenucci D, Towler M (2010) The role of open and closed curing conditions on the leaching properties of fly ash-slag-based geopolymers. J Hazard Mater 176:623-628

Jang J, Park S, Lee H (2016) Physical barrier effect of geopolymeric waste form on diffusivity of cesium and strontium. J Hazard Mater 318:339-346

Järup L (2003) Hazards of heavy metal contamination. Br Med Bull 68:167-182

Javadian H, Ghorbani F, Tayebi HA, Asl SH (2013) Study of the adsorption of $\mathrm{Cd}$ (II) from aqueous solution using zeolitebased geopolymer, synthesized from coal fly ash; kinetic, isotherm and thermodynamic studies. Arab $\mathrm{J}$ Chem 8:837-849

Ji Z, Yuan J, Li X (2007) Removal of ammonium from wastewater using calcium form clinoptilolite. J Hazard Mater 141:483-488

Jo M, Soto L, Arocho M, St John J, Hwang S (2015) Optimum mix design of fly ash geopolymer paste and its use in pervious concrete for removal of fecal coliforms and phosphorus in water. Constr Build Mater 93:1097-1104

Johari SA, Kalbassi MR, Soltani M, Yu IJ (2016) Application of nanosilver-coated zeolite as water filter media for fungal disinfection of rainbow trout (Oncorhynchus mykiss) eggs. Aquac Int 24:23-38

Kara I, Yilmazer D, Akar ST (2017) Metakaolin based geopolymer as an effective adsorbent for adsorption of zinc(II) and nickel(II) ions from aqueous solutions. Appl Clay Sci 139:54-63

Kara I, Tunc D, Sayin F, Akar ST (2018) Study on the performance of metakaolin based geopolymer for $\mathrm{Mn}$ (II) and Co(II) removal. Appl Clay Sci 161:184-193 
Kazemimoghadam M (2010) New nanopore zeolite membranes for water treatment. Desalination 251:176-180

Khale D, Chaudhary R (2007) Mechanism of geopolymerization and factors influencing its development: a review. J Mater Sci 42:729-746

Khan MI, Min TK, Azizli K, Sufian S, Ullah H, Man Z (2015) Effective removal of methylene blue from water using phosphoric acid based geopolymers: synthesis, characterizations and adsorption studies. RSC Adv 5:61410-61420

Kim JH, Gibb HJ, Howe PD (2006) Cobalt and inorganic cobalt compounds. World Health Organization, Geneva

Kinoshita N, Sueki K, Sasa K, Kitagawa J, Ikarashi S, Nishimura T, Wong YS, Satou Y, Handa K, Takahashi T, Sato M, Yamagata $\mathrm{T}$ (2011) Assessment of individual radionuclide distributions from the Fukushima nuclear accident covering central-east Japan. Proc Natl Acad Sci USA 108:19526-19529

Komnitsas K, Zaharaki D (2007) Geopolymerisation: a review and prospects for the minerals industry. Miner Eng 20:1261-1277

Kourti I, Devaraj AR, Bustos AG, Deegan D, Boccaccini AR, Cheeseman CR (2011) Geopolymers prepared from DC plasma treated air pollution control (APC) residues glass: properties and characterisation of the binder phase. J Hazard Mater 196:86-92

Kumar A, Kumar S (2013) Development of paving blocks from synergistic use of red mud and fly ash using geopolymerization. Constr Build Mater 38:865-871

Kunze C, Hermann E, Griebel I, Kiessig G, Dullies F, Schreiter M (2002) Entwicklung und praxiseinsatz eines hocheffizienten selektiven sorbens für radium. Wasser-Abwasser 143:572-577

LaGrega MD, Buckingham PL, Evans JC (1994) Hazardous waste management. McGraw-Hill Inc., New York

Lancellotti I, Kamseu E, Michelazzi M, Barbieri L, Corradi A, Leonelli C (2010) Chemical stability of geopolymers containing municipal solid waste incinerator fly ash. Waste Manag 30:673-679

Landi E, Medri V, Papa E, Dedecek J, Klein P, Benito P, Vaccari A (2013) Alkali-bonded ceramics with hierarchical tailored porosity. Appl Clay Sci 73:56-64

Lee N, Khalid HR, Lee H (2016a) Synthesis of mesoporous geopolymers containing zeolite phases by a hydrothermal treatment. Microporous Mesoporous Mater 229:22-30

Lee S, Van Riessen A, Chon C, Kang N, Jou H, Kim Y (2016b) Impact of activator type on the immobilisation of lead in fly ash-based geopolymer. J Hazard Mater 305:59-66

Lee NK, Khalid HR, Lee HK (2017) Adsorption characteristics of cesium onto mesoporous geopolymers containing nanocrystalline zeolites. Microporous Mesoporous Mater 242:238-244

Le-ping L, Xue-min C, Shu-heng Q, Jun-li Y, Lin Z (2010) Preparation of phosphoric acid-based porous geopolymers. Appl Clay Sci 50:600-603

Leyva-Ramos R, Monsivais-Rocha JE, Aragon-Piña A, BerberMendoza MS, Guerrero-Coronado RM, Alonso-Davila P, Mendoza-Barron J (2010) Removal of ammonium from aqueous solution by ion exchange on natural and modified chabazite. J Environ Manag 91:2662-2668
Li L, Wang S, Zhu Z (2006) Geopolymeric adsorbents from fly ash for dye removal from aqueous solution. J Colloid Interface Sci 300:52-59

Li C, Sun H, Li L (2010) A review: the comparison between alkali-activated slag ( $\mathrm{Si} \mathrm{Ca}$ ) and metakaolin ( $\mathrm{Si} \mathrm{Al}$ ) cements. Cem Concr Res 40:1341-1349

Li Q, Sun Z, Tao D, Xu Y, Li P, Cui H, Zhai J (2013) Immobilization of simulated radionuclide $133 \mathrm{Cs}$ by fly ash-based geopolymer. J Hazard Mater 262:325-331

Li C, He Y, Tang Q, Wang K, Cui X (2016a) Study of the preparation of $\mathrm{CdS}$ on the surface of geopolymer spheres and photocatalyst performance. Mater Chem Phys 178:204-210

Li Z, Ohnuki T, Ikeda K (2016b) Development of paper sludge ash-based geopolymer and application to treatment of hazardous water contaminated with radioisotopes. Mater 9:633

Li Q, He Y, Xu M, Liu J, He M, Huang L, Cui X (2017) Study on the removal of $\mathrm{Ca} 2+$ and $\mathrm{Mg} 2+$ in water by the geopolymer-based inorganic membrane. Gongneng Cailiao 48:01215-01220

Lima E (2010) Cesium. In: Atwood DA (ed) Radionuclides in the environment. Wiley, Chichester, pp 73-78

Lin Y, Guo M, Shah N, Stuckey DC (2016) Economic and environmental evaluation of nitrogen removal and recovery methods from wastewater. Bioresour Technol 215:227-238

Liu X, Chen GR, Lee DJ, Kawamoto T, Tanaka H, Chen ML, Luo YK (2014) Adsorption removal of cesium from drinking waters: a mini review on use of biosorbents and other adsorbents. Bioresour Technol 160:142-149

Liu Y, Yan C, Qiu X, Li D, Wang H, Alshameri A (2016a) Preparation of faujasite block from fly ash-based geopolymer via in situ hydrothermal method. J Taiwan Inst Chem Eng 59:433-439

Liu Y, Yan C, Zhang Z, Wang H, Zhou S, Zhou W (2016b) A comparative study on fly ash, geopolymer and faujasite block for $\mathrm{Pb}$ removal from aqueous solution. Fuel 185:181-189

Liu Y, Yan C, Zhang Z, Gong Y, Wang H, Qiu X (2016c) A facile method for preparation of floatable and permeable fly ash-based geopolymer block. Mater Lett 185:370-373

Liu Y, Yan C, Zhang Z, Li L, Wang H, Pu S (2017) One-step fabrication of novel porous and permeable self-supporting zeolite block from fly ash. Mater Lett 196:328-331

Lloyd RR, Provis JL, van Deventer JS (2010) Pore solution composition and alkali diffusion in inorganic polymer cement. Cem Concr Res 40:1386-1392

López FJ, Sugita S, Kobayashi T (2014a) Cesium-adsorbent geopolymer foams based on silica from rice husk and metakaolin. Chem Lett 43:128-130

López FJ, Sugita S, Tagaya M, Kobayashi T (2014b) Metakaolin-based geopolymers for targeted adsorbents to heavy metal ion separation. J Mater Sci Chem Eng 2:16-27

Louati S, Baklouti S, Samet B (2016a) Acid based geopolymerization kinetics: effect of clay particle size. Appl Clay Sci 132-133:571-578

Louati S, Baklouti S, Samet B (2016b) Geopolymers based on phosphoric acid and illito-kaolinitic clay. Adv Mater Sci Eng 2016:1-7 
Luukkonen T, Runtti H, Niskanen M, Tolonen ET, Sarkkinen M, Kemppainen K, Rämö J, Lassi U (2016a) Simultaneous removal of $\mathrm{Ni}(\mathrm{II}), \mathrm{As}(\mathrm{III})$, and $\mathrm{Sb}$ (III) from spiked mine effluent with metakaolin and blast-furnace-slag geopolymers. J Environ Manag 166:579-588

Luukkonen T, Sarkkinen M, Kemppainen K, Rämö J, Lassi U (2016b) Metakaolin geopolymer characterization and application for ammonium removal from model solutions and landfill leachate. Appl Clay Sci 119:266-276

Luukkonen T, Tolonen ET, Runtti H, Kemppainen K, Perämäki P, Rämö J, Lassi U (2017a) Optimization of the metakaolin geopolymer preparation for maximized ammonium adsorption capacity. J Mater Sci 52:9363-9376

Luukkonen T, Vežníková K, Tolonen E-, Runtti H, Yliniemi J, $\mathrm{Hu}$ T, Kemppainen K, Lassi U (2017b) Removal of ammonium from municipal wastewater with powdered and granulated metakaolin geopolymer. Environ Technol 1-10

Luukkonen T, Abdollahnejad Z, Yliniemi J, Kinnunen P, Illikainen M (2018) Comparison of alkali and silica sources in one-part alkali-activated blast furnace slag mortar. J Clean Prod 187:171-179

Mackenzie KJD (2011) Inorganic polymers for environmental protection applications. IOP Conf Ser Mater Sci Eng 18:172001

MacKenzie KJD (2014) Innovative applications of inorganic polymers (geopolymers). In: Pacheco-Torgal F, Labrincha J, Leonelli C, Palomo A, Chindaprasit P (eds) Handbook of alkali-activated cements, mortars and concretes. Woodhead Publishing, Cambridge, pp 777-805

Majidi B (2009) Geopolymer technology, from fundamentals to advanced applications: a review. Mater Technol 24:79-87

Mallicoat S, Sarin P, Kriven W (2005) Novel, alkali-bonded, ceramic filtration membranes. Ceram Eng Sci Proc 26:37-44

Materials Characterization Center (MCC) (1981) Nuclear waste materials handbook. DOE/TIC-1140. Materials Characterization Center, Pacific Northwest Laboratory, Richland

Mehta A, Siddique R (2016) An overview of geopolymers derived from industrial by-products. Constr Build Mater 127:183-198

Mohammadi F, Mohammadi T (2017) Optimal conditions of porous ceramic membrane synthesis based on alkali activated blast furnace slag using Taguchi method. Ceram Int 43:14369-14379

Mohd Salahuddin MB, Norkhairunnisa M, Mustapha F (2015) A review on thermophysical evaluation of alkali-activated geopolymers. Ceram Int 41:4273-4281

Mpenyana-Monyatsi L, Mthombeni NH, Onyango MS, Momba MNB (2012) Cost-effective filter materials coated with silver nanoparticles for the removal of pathogenic bacteria in groundwater. Int J Environ Res Public Health 9:244-271

Mužek MN, Svilovic S, Zelic J (2014) Fly ash-based geopolymeric adsorbent for copper ion removal from wastewater. Desalin Water Treat 52:2519-2526

Mužek MN, Svilović S, Zelić J (2016a) Kinetic studies of cobalt ion removal from aqueous solutions using fly ash-based geopolymer and zeolite $\mathrm{NaX}$ as sorbents. Sep Sci Technol 51:2868-2875

Mužek MN, Svilovic S, Ugrina M, Zelic J (2016b) Removal of copper and cobalt ions by fly ash-based geopolymer from solutions-equilibrium study. Desalin Water Treat 57:10689-10699

Myers RJ, Bernal SA, San Nicolas R, Provis JL (2013) Generalized structural description of calcium-sodium aluminosilicate hydrate gels: the cross-linked substituted tobermorite model. Langmuir 29:5294-5306

Myers RJ, Bernal SA, Provis JL (2014) A thermodynamic model for C-(N-)A-S-H gel: CNASH_ss. Derivation and validation. Cem Concr Res 66:27-47

Naghsh M, Shams K (2017) Synthesis of a kaolin-based geopolymer using a novel fusion method and its application in effective water softening. Appl Clay Sci 146:238-245

NEN 7341 (1995) Leaching Characteristics of Solid (Earthy and Stony) Building and Waste Materials. Leaching Tests. Determination of the Availability of Inorganic Components for Leaching. Netherlands Standardization Institute

NEN 7345 (1995) Leaching Characteristics of Solid Earthy and Stony Building and Waste Materials. Determination of the Availability of Inorganic Components for Leaching. Netherlands Standardization Institute

NEN 7375 (2004) Leaching characteristics-determination of the leaching of inorganic components from moulded Or monolithic materials with the diffusion test—solid earthy and stony materials. Netherlands Standardization Institute

Nikolić I, Đurović D, Blečić D, Zejak R, Karanović L, Mitsche S, Radmilović V (2013) Geopolymerization of coal fly ash in the presence of electric arc furnace dust. Miner Eng 49:24-32

Nikolić V, Komljenović M, Marjanović N, Baščarević Z, Petrović $\mathrm{R}$ (2014) Lead immobilization by geopolymers based on mechanically activated fly ash. Ceram Int 40:8479-8488

Nimwinya E, Arjharn W, Horpibulsuk S, Phoo-Ngernkham T, Poowancum A (2016) A sustainable calcined water treatment sludge and rice husk ash geopolymer. J Clean Prod 119:128-134

Niu Y, Zhao Y, Xi B, Hu X, Xia X, Wang L, Lv D, Lu J (2012) Removal of ammonium from aqueous solutions using synthetic zeolite obtained from coal fly-ash. Fresenius Environ Bull 21:1732-1739

Novais RM, Buruberri LH, Seabra MP, Bajare D, Labrincha JA (2016a) Novel porous fly ash-containing geopolymers for pH buffering applications. J Clean Prod 124:395-404

Novais RM, Buruberri LH, Seabra MP, Labrincha JA (2016b) Novel porous fly-ash containing geopolymer monoliths for lead adsorption from wastewaters. J Hazard Mater 318:631-640

Novais RM, Seabra MP, Labrincha JA (2017) Porous geopolymer spheres as novel $\mathrm{pH}$ buffering materials. J Clean Prod 143:1114-1122

Obonyo E, Kamseu E, Melo UC, Leonelli C (2011) Advancing the use of secondary inputs in geopolymer binders for sustainable cementitious composites: a review. Sustainability 3:410-423

O’Connor SJ, MacKenzie KJD, Smith ME, Hanna JV (2010) Ion exchange in the charge-balancing sites of aluminosilicate inorganic polymers 20:10234-10240

Ogundiran M, Nugteren H, Witkamp G (2013) Immobilisation of lead smelting slag within spent aluminate-fly ash based geopolymers. J Hazard Mater 248:29-36 
Onisei S, Pontikes Y, Van Gerven T, Angelopoulos G, Velea T, Predica V, Moldovan P (2012) Synthesis of inorganic polymers using fly ash and primary lead slag. J Hazard Mater 205:101-110

Onutai S, Kobayashi T, Thavorniti P, Jiemsirilers S (2018) The adsorption of cadmium ions on fly ash based geopolymer particles. In: Key engineering materials (KEM), vol 766, pp 65-70

Pacheco-Torgal F, Abdollahnejad Z, Camões AF, Jamshidi M, Ding Y (2012) Durability of alkali-activated binders: a clear advantage over Portland cement or an unproven issue? Constr Build Mater 30:400-405

Panda L, Rath SS, Rao DS, Nayak BB, Das B, Misra PK (2018) Thorough understanding of the kinetics and mechanism of heavy metal adsorption onto a pyrophyllite mine waste based geopolymer 263:428-441

Part WK, Ramli M, Cheah CB (2015) An overview on the influence of various factors on the properties of geopolymer concrete derived from industrial by-products. Constr Build Mater 77:370-395

Pereira CF, Luna Y, Querol X, Antenucci D, Vale J (2009) Waste stabilization/solidification of an electric arc furnace dust using fly ash-based geopolymers. Fuel 88:1185-1193

Pérez-González A, Urtiaga AM, Ibáñez R, Ortiz I (2012) State of the art and review on the treatment technologies of water reverse osmosis concentrates. Water Res 46:267-283

Pesonen J, Yliniemi J, Illikainen M, Kuokkanen T, Lassi U (2016) Stabilization/solidification of fly ash from fluidized bed combustion of recovered fuel and biofuel using alkali activation and cement addition. J Environ Chem Eng 4:1759-1768

Phair J, Van Deventer J (2001) Effect of silicate activator pH on the leaching and material characteristics of waste-based inorganic polymers. Miner Eng 14:289-304

Phair J, Van Deventer J, Smith J (2004) Effect of Al source and alkali activation on $\mathrm{Pb}$ and $\mathrm{Cu}$ immobilisation in fly-ash based "geopolymers". Appl Geochem 19:423-434

Pimraksa K, Chindaprasirt P, Rungchet A, Sagoe-Crentsil K, Sato T (2011) Lightweight geopolymer made of highly porous siliceous materials with various $\mathrm{Na}_{2} \mathrm{O} / \mathrm{Al}_{2} \mathrm{O}_{3}$ and $\mathrm{SiO}_{2} / \mathrm{Al}_{2} \mathrm{O}_{3}$ ratios. Mater Sci Eng, A 528:6616-6623

Ponzoni C, Lancellotti I, Barbieri L, Spinella A, Saladino ML, Martino DC, Caponetti E, Armetta F, Leonelli C (2015) Chromium liquid waste inertization in an inorganic alkali activated matrix: leaching and NMR multinuclear approach. J Hazard Mater 286:474-483

Poowancum A, Nimwinya E, Horpibulsuk S (2015) Development of room temperature curing geopolymer from calcined water-treatment-sludge and rice husk ash. In: Scrivener K, Favier A (eds) Calcined clays for sustainable concrete. Springer, Dordrecht, pp 291-297

Provis JL (2014a) Introduction and scope. In: Provis JL, Van Deventer JSJ (eds) Alkali activated materials, state-of-theart report, RILEM TC 224-AAM. Springer, Dordrecht, pp 1-9

Provis JL (2014b) Geopolymers and other alkali activated materials: why, how, and what? Mater Struct 47:11-25

Provis JL (2018) Alkali-activated materials. Cem Concr Res 114:40-48

Provis J, Van Deventer J (2007) Geopolymerisation kinetics. 2. Reaction kinetic modelling. Chem Eng Sci 62:2318-2329
Provis JL, van Deventer JSJ (2009) Introduction to geopolymers. In: Provis JL, Van Deventer JSJ (eds) Geopolymers: structure, processing, properties and industrial applications. Woodhead Publishing and CRC Press, Cambridge and Boca Raton, pp 1-11

Provis JL, Duxson P, van Deventer JSJ (2010) The role of particle technology in developing sustainable construction materials. Adv Powder Technol 21:2-7

Provis JL, Fernández-Jiménez A, Kamseu E, Leonelli C, Palomo A (2014) Binder chemistry: low-calcium alkaliactivated materials. In: Anonymous Alkali Activated Materials, State-of-the-Art Report, RILEM TC 224-AAM. Springer, Dordrecht, pp 93-123

Provis L, Palomo A, Shi C (2015) Advances in understanding alkali-activated materials. Cem Concr Res 78:110-125

Rafatullah M, Sulaiman O, Hashim R, Ahmad A (2010) Adsorption of methylene blue on low-cost adsorbents: a review. J Hazard Mater 177:70-80

Rao F, Liu Q (2015) Geopolymerization and its potential application in mine tailings consolidation: a review. Miner Process Extr Metal Rev 36:399-409

Rauret G, Lopez-Sanchez J, Sahuquillo A, Rubio R, Davidson C, Ure A, Quevauviller P (1999) Improvement of the BCR three step sequential extraction procedure prior to the certification of new sediment and soil reference materials. J Environ Monit 1:57-61

Rees C (2007) Mechanisms and kinetics of gel formation in geopolymers, Ph.D. thesis. University of Melbourne

Rees CA, Provis JL, Lukey GC, van Deventer JSJ (2008) The mechanism of geopolymer gel formation investigated through seeded nucleation. Colloids Surf Physicochem Eng Aspects 318:97-105

Rowles M, Hanna JV, Pike K, Smith ME, O'Connor B (2007) ${ }^{29} \mathrm{Si},{ }^{27} \mathrm{Al},{ }^{1} \mathrm{H}$ and ${ }^{23} \mathrm{Na}$ MAS NMR study of the bonding character in aluminosilicate inorganic polymers. Appl Magn Reson 32:663-689

Runtti H, Luukkonen T, Niskanen M, Tuomikoski S, Kangas T, Tynjälä P, Tolonen ET, Sarkkinen M, Kemppainen K, Rämö J, Lassi U (2016) Sulphate removal over bariummodified blast-furnace-slag geopolymer. J Hazard Mater 317:373-384

Sarioglu M (2005) Removal of ammonium from municipal wastewater using natural Turkish (Dogantepe) zeolite. Sep Purif Technol 41:1-11

Sarkar C, Basu JK, Samanta AN (2017) Removal of $\mathrm{Ni}^{2+}$ ion from waste water by geopolymeric adsorbent derived from LD Slag. J Water Proc Eng 17:237-244

Sarkar C, Basu JK, Samanta AN (2018) Synthesis of mesoporous geopolymeric powder from LD slag as superior adsorbent for Zinc (II) removal. Adv Powder Technol 29:1142-1152

Schoenung JM (2008) Lead compounds. In: Shackelford JF, Doremus RH (eds) Ceramic and glass materials: structure, properties and processing. Springer, New York, pp 151-167

Shaikh FUA (2013) Review of mechanical properties of short fibre reinforced geopolymer composites. Constr Build Mater 43:37-49

Silva I, Castro-Gomes J, Albuquerque A (2012) Mineral waste geopolymeric artificial aggregates as alternative materials for wastewater-treatment processes: study of structural 
stability and $\mathrm{pH}$ variation in water. J Mater Civ Eng 24:623-628

Singh B, Ishwarya G, Gupta M, Bhattacharyya SK (2015) Geopolymer concrete: a review of some recent developments. Constr Build Mater 85:78-90

Singhal A, Gangwar BP, Gayathry JM (2017) CTAB modified large surface area nanoporous geopolymer with high adsorption capacity for copper ion removal 150:106-114

Siyal AA, Shamsuddin MR, Khan MI, Rabat NE, Zulfiqar M, Man Z, Siame J, Azizli KA (2018) A review on geopolymers as emerging materials for the adsorption of heavy metals and dyes 224:327-339

Skorina T (2014) Ion exchange in amorphous alkali-activated aluminosilicates: potassium based geopolymers. Appl Clay Sci 87:205-211

Strozi Cilla M, Colombo P, Raymundo Morelli M (2014a) Geopolymer foams by gelcasting. Ceram Int 40:5723-5730

Strozi Cilla M, Raymundo Morelli M, Colombo P (2014b) Effect of process parameters on the physical properties of porous geopolymers obtained by gelcasting. Ceram Int 40:13585-13590

Suksiripattanapong C, Srijumpa T, Horpibulsuk S, Sukmak P, Arulrajah A, Du Y (2015a) Compressive strengths of water treatment sludge-fly ash geopolymer at various compression energies. Lowland Technol Int 17:147-156

Suksiripattanapong C, Horpibulsuk S, Boongrasan S, Udomchai A, Chinkulkijniwat A, Arulrajah A (2015b) Unit weight, strength and microstructure of a water treatment sludge-fly ash lightweight cellular geopolymer. Constr Build Mater 94:807-816

Suksiripattanapong C, Horpibulsuk S, Chanprasert P, Sukmak $\mathrm{P}$, Arulrajah A (2015c) Compressive strength development in fly ash geopolymer masonry units manufactured from water treatment sludge. Constr Build Mater 82:20-30

Sullivan C, Tyrer M, Cheeseman CR, Graham NJ (2010) Disposal of water treatment wastes containing arsenic: a review. Sci Total Environ 408:1770-1778

SW-846 Test Method 1311 (1992) Toxicity Characteristic Leaching Procedure. United States Environmental Protection Agency

SW-846 Test Method 1312 (1994) Synthetic Precipitation Leaching Procedure. United States Environmental Protection Agency

SW-846 Test Method 1313 Liquid-Solid Partitioning as a Function of Extract pH using a Parallel Batch Extraction Procedure. United States Environmental Protection Agency

Tang Q, Ge Y, Wang K, He Y, Cui X (2015) Preparation and characterization of porous metakaolin-based inorganic polymer spheres as an adsorbent. Mater Des 88:1244-1249

Tchounwou PB, Yedjou CG, Patlolla AK, Sutton DJ (2012) Heavy metal toxicity and the environment. EXS 101:133-164

Tessier A, Campbell PG, Bisson M (1979) Sequential extraction procedure for the speciation of particulate trace metals. Anal Chem 51:844-851

Van Jaarsveld JGS, Van Deventer JSJ, Schwartzman A (1999) The potential use of geopolymeric materials to immobilise toxic metals: Part II. Material and leaching characteristics. Miner Eng 12:75-91
Wagh AS (2005) Chemically bonded phosphate ceramics: a novel class of geopolymers. Ceram Trans 165:107-116

Waijarean N, Asavapisit S, Sombatsompop K (2014) Strength and microstructure of water treatment residue-based geopolymers containing heavy metals. Constr Build Mater 50:486-491

Walkley B, Nicolas RS, Marc-Antoine S, Rees GJ, Hanna JV, van Deventer JSJ, Provis JL (2016) Phase evolution of $\mathrm{C}-(\mathrm{N})-\mathrm{A}-\mathrm{S}-\mathrm{H} / \mathrm{N}-\mathrm{A}-\mathrm{S}-\mathrm{H}$ gel blends investigated via alkaliactivation of synthetic calcium aluminosilicate precursors. Cem Concr Res 89:120-135

Wan Q, Rao F, Song S, García RE, Estrella RM, Patiño CL, Zhang Y (2017) Geopolymerization reaction, microstructure and simulation of metakaolin-based geopolymers at extended Si/Al ratios. Cem Concr Compos 79:45-52

Wang S, Li L, Zhu ZH (2007) Solid-state conversion of fly ash to effective adsorbents for $\mathrm{Cu}$ removal from wastewater. J Hazard Mater 139:254-259

Wang YS, Dai JG, Ding Z, Xu WT (2017) Phosphate-based geopolymer: formation mechanism and thermal stability. Mater Lett 190:209-212

World Health Organization (2011a) Guidelines for drinkingwater quality. WHO Press, Geneva

World Health Organization (2011b) Hardness in Drinking-water, Background document for development of WHO Guidelines for Drinking-water Quality. WHO/HSE/WSH/ 10.01/10/Rev/1. WHO Press, Geneva, Switzerland

Xu Z, Yang Z, Zhang J, Zhang M (2013) Preparation technology and properties of sludge-high calcium coal waste geopolymer. Fuhe Cailiao Xuebao 30:113-118

Xu MX, He Y, Wang CQ, He XF, He XQ, Liu J, Cui XM (2015) Preparation and characterization of a self-supporting inorganic membrane based on metakaolin-based geopolymers. Appl Clay Sci 115:254-259

Xu M, He Y, Wang Y, Cui X (2017) Preparation of a nonhydrothermal NaA zeolite membrane and defect elimination by vacuum-inhalation repair method. Chem Eng Sci 158:117-123

Xuemin C, Yan H, Leping L, Jinyu C (2011) NaA zeolite synthesis from geopolymer precursor. MRS Commun 1:49-51

Yan H, Xue-Min C, Jin M, Liu L-, Liu X-, Chen J- (2012) The hydrothermal transformation of solid geopolymers into zeolites. Microporous Mesoporous Mater 161:187-192

Yan Z-, Wang J-, Wu Y-, Zhang X- (2016) Preparation and characterization of activated carbon from deinking sludge activated by potassium hydroxide. Zhongguo Zaozh Xuebao 31:32-36

Yang ZX, Ha NR, Jang MS, Hwang KH, Lee JK (2009) The effect of $\mathrm{SiO}_{2}$ on the performance of inorganic sludgebased structural concretes. J Ceram Process Res 10:266-268

Yang ZX, Ha NR, Jang MS, Hwang KH, Jun BS, Lee JK (2010) The performance of geopolymer based on recycled concrete sludge. Ceram Trans 210:221-224

Yang K-, Lo C-, Huang J- (2013a) Production and properties of foamed reservoir sludge inorganic polymers. Cem Concr Compos 38:50-56

Yang ZX, Zhao JM, Hwang KH, Shin SJ, Lee HR (2013b) Strength enhancement of sludge based geopolymer by Si/ Al ratio variation. Adv Mater Res 610-613:518-521 
Ye Z, Wang J, Sun L, Zhang D, Zhang H (2015) Removal of ammonium from municipal landfill leachate using natural zeolites. Environ Technol 36:2919-2923

Yliniemi J, Pesonen J, Tiainen M, Illikainen M (2015) Alkali activation of recovered fuel-biofuel fly ash from fluidisedbed combustion: stabilisation/solidification of heavy metals. Waste Manage 43:273-282

Yousef RI, El-Eswed B, Alshaaer M, Khalili F, Khoury H (2009) The influence of using Jordanian natural zeolite on the adsorption, physical, and mechanical properties of geopolymers products. J Hazard Mater 165:379-387

Yunsheng Z, Wei S, Qianli C, Lin C (2007) Synthesis and heavy metal immobilization behaviors of slag based geopolymer. J Hazard Mater 143:206-213

Zhang Y, Liu L (2013) Fly ash-based geopolymer as a novel photocatalyst for degradation of dye from wastewater 11:353-358

Zhang M, Zhang H, Xu D, Han L, Niu D, Tian B, Zhang J, Zhang L, Wu W (2011) Removal of ammonium from aqueous solutions using zeolite synthesized from fly ash by a fusion method. Desalination 271:111-121

Zhang J, He Y, Wang Y, Mao J, Cui X (2014) Synthesis of a selfsupporting faujasite zeolite membrane using geopolymer gel for separation of alcohol/water mixture. Mater Lett 116:167-170
Zhang Z, Li L, He D, Ma X, Yan C, Wang H (2016) Novel selfsupporting zeolitic block with tunable porosity and crystallinity for water treatment. Mater Lett 178:151-154

Zhang YJ, He PY, Yang MY, Kang L (2017) A new graphene bottom ash geopolymeric composite for photocatalytic $\mathrm{H}_{2}$ production and degradation of dyeing wastewater. Int $\mathbf{J}$ Hydr Energy 42:20589-20598

Zhang Y, Li T, Hou D, Zhang J, Jiang J (2018) Insights on magnesium and sulfate ions' adsorption on the surface of sodium alumino-silicate hydrate (NASH) gel: a molecular dynamics study. Phys Chem Chem Phys 20:18297-18310

Zheng L, Wang W, Gao X (2016) Solidification and immobilization of MSWI fly ash through aluminate geopolymerization: based on partial charge model analysis. Waste Manage 58:270-279

Zhuang XY, Chen L, Komarneni S, Zhou CH, Tong DS, Yang HM, Yu WH, Wang H (2016) Fly ash-based geopolymer: clean production, properties and applications. J Clean Prod 125:253-267

Publisher's Note Springer Nature remains neutral with regard to jurisdictional claims in published maps and institutional affiliations. 